\title{
Synthesis of Poly(silyl ether)s by Rh(I)-NHC Catalysed Hydrosilylation: Homogeneous versus Heterogeneous Catalysis
}

\author{
Guillermo Lázaro, Manuel Iglesias, Francisco J. Fernández-Alvarez," Pablo J. \\ Sanz Miguel, Jesús J. Pérez-Torrente and Luis A. Oro*
}

The preparation of 1-(3-triisopropoxysilylpropyl)-3-(2-methoxyethyl)imidazolium bromide or chloride salts and their reaction with $[\mathrm{Rh}(\mathrm{COD})(\mu-\mathrm{OMe})]_{2} \quad(\mathrm{COD}=1,5$-cyclooctadiene $)$ to afford the corresponding $[\mathrm{Rh}(\mathrm{COD})(\mathrm{NHC}) \mathrm{X}] \quad(\mathrm{X}=\mathrm{Br}, \mathrm{Cl}) \quad(\mathrm{NHC}=1-(3-$ triisopropoxysilylpropyl)-3-(2-methoxyethyl)-2-ilydene-imidazol) species is described. These new compounds were used as catalysts precursors for acetophenone hydrosilylation. The higher activity of the rhodium-chlorido complex evidences a clear halide effect in the activation of the catalyst. Immobilization of the catalytic precursor $[\mathrm{Rh}(\mathrm{COD})(\mathrm{NHC}) \mathrm{Cl}]$ on $\mathrm{MCM}-41$ allows the preparation of the corresponding heterogeneous catalyst. Reduction of acetophenone to

\section{Introduction}

Transition metal catalysed hydrosilylation can be considered one of the most fascinating chemical transformations in organometallic chemistry. ${ }^{[1]}$ The most efficient catalytic systems for hydrosilylation are based on Pt- or Rh-catalysts. ${ }^{[1]}$ However, such precious metal species are extremely expensive with diminishing reserves. Consequently, the development of highly selective and easily recyclable new catalysts is of great interest.

On the other hand, there is an increasing interest on the immobilization of homogeneous catalysts onto supports producing heterogeneous catalysts that could maintain the selectivity of the former homogeneous catalytic system and that would be easily recycled. ${ }^{[2]}$

The use of $\mathrm{N}$-heterocyclic carbenes (NHCs) as ligands has provided some significant improvements on the catalytic activity of several homogeneous systems. ${ }^{[3]}$ Pioneering work on homogeneous catalysts based on a transition metal-NHC species was reported by Herrmann's group in $1995 .{ }^{[4]}$ Since then, many transition metal complexes bearing $\mathrm{NHC}$ ligands have shown to be active homogeneous catalysts. In particular, rhodium complexes containing NHC carbenes demonstrated to be effective hydrosilylation catalysts. ${ }^{[5]}$ During the last decade, immobilisation of metal-NHC catalysts has become a field of great interest, being the immobilization of homogeneous catalysts without a decrease in the catalytic activity and selectivity of the active species a major goal. ${ }^{[2,6]}$

Rh-catalysed hydrosilylation of ketones is a well-established process. ${ }^{[1]}$ However, further improvement of the catalytic activity and selectivity still remain a challenge.$^{[1,7]}$ Catalytic hydrosilylation provides a convenient route for the synthesis of new functional materials ${ }^{[8]}$ such as poly(silyl ether)s. ${ }^{[9]}$ The backbones of poly(silyl ether)s contain $\mathrm{Si}-\mathrm{O}-\mathrm{Si}$ and $\mathrm{Si}-\mathrm{O}-\mathrm{C}$ bonds, being the latter hydrolytically more reactive. ${ }^{[10,11]}$ The hydrolytic reactivity of poly(silyl ether)s makes them attractive in many applications, such as, biodegradable materials or controlled release of drugs. $^{[12]}$
PhMeCH-O-SiMe $\left(\mathrm{OSiMe}_{3}\right)_{2}$ by hydrosilylation with $1,1,1,3,5,5,5-$ heptamethyltrisiloxane is effectively catalysed by both the homogeneous and the heterogeneous catalysts, being the homogenous system more active. Interestingly, the heterogeneous catalyst is reusable. Both homo- and heterogeneous catalysts are also effective for the copolymerization of terephthalaldehyde and 1,1,3,3,5,5-hexamethyltrisiloxane affording the corresponding poly(silyl ether), yielding the heterogeneous system polymers with higher molecular weights $(\mathrm{Mw}=94.000)$ and a narrow molecular weight distribution $(\mathrm{PDI}=1.5-1.7)$.

Poly(silyl ether)s have traditionally been prepared by policondensation of dichlorosilanes, diphenoxysilanes or diaminosilanes with various diols. ${ }^{[13]}$ Lately, a number of poly(silyl ether)s have been obtained by metal-catalysed hydrosilylation using $\left[\mathrm{Ru}(\mathrm{CO}) \mathrm{H}_{2}\left(\mathrm{PPh}_{3}\right)_{3}\right]$ as catalyst precursor. ${ }^{[10,14]}$ To the best of our knowledge, examples of rhodium-catalysed synthesis of poly(silyl ether)s have not yet been reported.

Recently, our research group has demonstrated that rhodium(I)$\mathrm{NHC}$ complexes bearing hemilabile $\mathrm{NHC}$ ligands are efficient and selective catalysts for alkyne hydrosilylation ${ }^{[15 a]}$ and hydrogen transfer hydrogenation. ${ }^{[15 b]}$ In this context, a number of complexes containing $\mathrm{O}-, \mathrm{N}-$, or S-functionalized $\mathrm{NHC}$ hemilabile ligands have been synthetized, with an active role of the labile fragment in some catalytic processes. ${ }^{[16]}$

As a variation of the work of our group on the chemistry of rhodium-NHC species, ${ }^{[15,16 a, 17]}$ here we report the synthesis and characterization of new rhodium-NHC complexes containing a doubly functionalized $\mathrm{NHC}$ ligand with a labile O-donor fragment and a triisopropoxysilyl tail group, O-donor-functionalized NHC ligand, together with the study of their activity as ketone hydrosilylation catalysts. Moreover, the new rhodium-NHC species was immobilized on MCM- 41 in order to compare the effects exerted by the solid on the activity, selectivity and recyclability of the catalyst. Finally, we have studied the potential applicability of the new catalytic systems in the synthesis of poly(silyl ether)s by Rh-catalysed hydrosilylation.

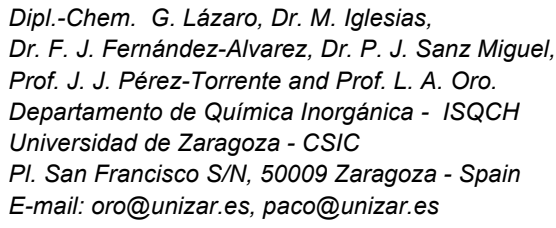




\section{Results and Discussion}

The synthesis of $\mathrm{NHC}$ ligands via deprotonation of the 2-carbon is one of the most important chemical applications of imidazolium salts. ${ }^{[18]}$ Particularly, $\mathrm{Si}(\mathrm{OR})_{3}$-functionalized imidazolium salts have proved to be useful precursors to prepare $\mathrm{Si}(\mathrm{OR})_{3^{-}}$ functionalized metal-NHC catalysts easy to immobilize on mineral supports. ${ }^{[19,20,21]}$

The imidazolium salt 1-(3-triisopropoxysilylpropyl)-3-(2methoxyethyl)-imidazolium bromide ([2]Br), used as precursor in this work, was synthesized by treatment of the 1-substituted imidazole 1 with 3-bromopropyltriisopropoxysilane in acetonitrile at $90^{\circ} \mathrm{C}$ (Scheme 1). [2] Br was isolated as an off-white oily solid in $84 \%$ yield according to Scheme 1 . The off-white chlorido salt [2]Cl was prepared in good yield $(\approx 90 \%$, Scheme 1$)$ passing a dichlomethane solution of the imidazolium bromide salt [2] Br through an ion exchange column packed with Dowex® 1X8-100 chloride form resin. Both [2] $\mathrm{Br}$ and [2] Cl have been characterized by elemental analysis, mass spectrometry $\left(\mathrm{ES}^{+}\right),{ }^{1} \mathrm{H}$ and ${ }^{13} \mathrm{C}\left\{{ }^{1} \mathrm{H}\right\}$ NMR spectroscopy.

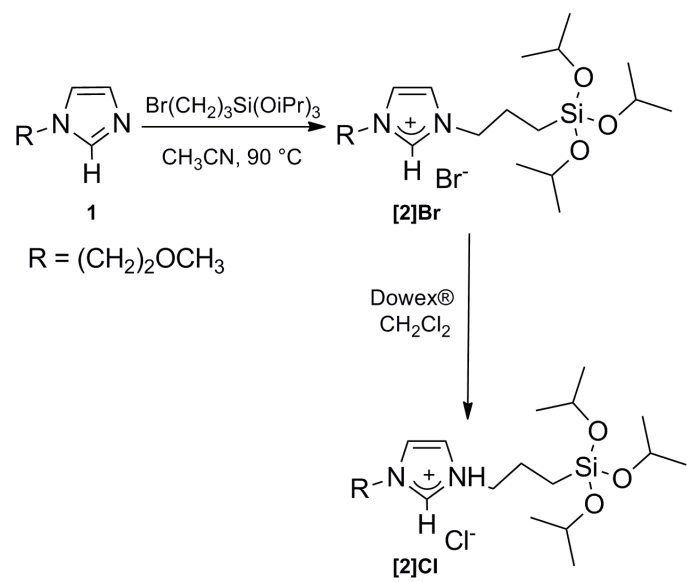

Scheme 1.

The ${ }^{1} \mathrm{H}$ NMR spectra of cations [2] ${ }^{+}$depend on the counter ion which is in agreement with a weak $\mathrm{C}(2)-\mathrm{H} \cdots \mathrm{X}(\mathrm{X}=\mathrm{Br}, \mathrm{Cl})$ interaction. ${ }^{[22]}$ The characteristic $\mathrm{NCHN}$ resonance appears downfield shifted as a singlet at $\delta 10.12 \mathrm{ppm}(2[\mathrm{Br}])$ and $\delta 10.24$ ppm $(2[\mathrm{Cl}])$. The isopropoxy groups of the $-\left(\mathrm{CH}_{2}\right) \mathrm{Si}\left(\mathrm{O}^{\mathrm{P}} \mathrm{Pr}\right)_{3}$ moiety are observed as a septuplet at around $\delta 4.2 \mathrm{ppm}\left(\mathrm{CH}^{\mathrm{i}} \mathrm{PrO}\right)$ and as a doublet at around $\delta 1.2 \mathrm{ppm}\left(\mathrm{CH}_{3}{ }^{-} \mathrm{PrO}\right)$ with a coupling constant of $6.0 \mathrm{~Hz}$. The $\mathrm{CH}_{2} \mathrm{Si}$ protons appear as a characteristic multiplet at around $\delta 0.5 \mathrm{ppm}$. The remaining resonances of the ${ }^{1} \mathrm{H}$ and ${ }^{13} \mathrm{C}\left\{{ }^{1} \mathrm{H}\right\}$ NMR spectra are consistent with the structure proposed in Scheme 1 for such compounds. The most noticeable resonances in the ${ }^{13} \mathrm{C}\left\{{ }^{1} \mathrm{H}\right\}$ NMR spectra are those due to the carbon atoms of the $-\left(\mathrm{CH}_{2}\right)_{3} \mathrm{Si}\left(\mathrm{O}^{\prime} \mathrm{Pr}\right)_{3}$ tail substituent, which are observed at around $\delta 8.5 \mathrm{ppm}\left(\mathrm{CH}_{2} \mathrm{Si}\right), 25.7 \mathrm{ppm}\left(\mathrm{CH}_{2}\right), 51.8$ $\left(\mathrm{NCH}_{2}\right)$ ppm, $65.5 \mathrm{ppm}(\mathrm{CH}-\mathrm{Pr})$ and $25.6 \mathrm{ppm}\left(\mathrm{CH}_{3}{ }^{-} \mathrm{Pr}\right)$.

Preparation of $\mathrm{Si}\left(\mathrm{O}^{\mathrm{i}} \mathrm{Pr}\right)_{3}$-functionalized rhodium(I)-NHC complexes. Complexes $[\mathrm{Rh}(\mathrm{COD})(2-$ methoxyethyl-NHC$\left.\left.\left(\mathrm{CH}_{2}\right)_{3} \mathrm{Si}\left(\mathrm{O}^{\prime} \mathrm{Pr}_{3}\right)_{3}\right) \mathrm{X}\right] \quad(\mathrm{X}=\mathrm{Br} \quad(\mathbf{3 a}), \quad \mathrm{Cl} \quad(\mathbf{3 b})) \quad(\mathrm{NHC}=1-(3-$ triisopropoxysilylpropyl)-3-(2-methoxyethyl)-2-ilydene-imidazol) were prepared by treatment of the corresponding imidazolium salt with 0.5 equiv of $[\mathrm{Rh}(\mathrm{COD})(\mu-\mathrm{OMe})]_{2}(\mathrm{COD}=1,5$-cyclooctadiene $)$ in $\mathrm{CH}_{2} \mathrm{Cl}_{2}$ at room temperature (Scheme 2). The new $\mathrm{Rh}^{\prime}-\mathrm{NHC}$ complexes were isolated, after recrystallization, as pure yellow crystalline solids in $\approx 90 \%$ yield according to Scheme 2 .

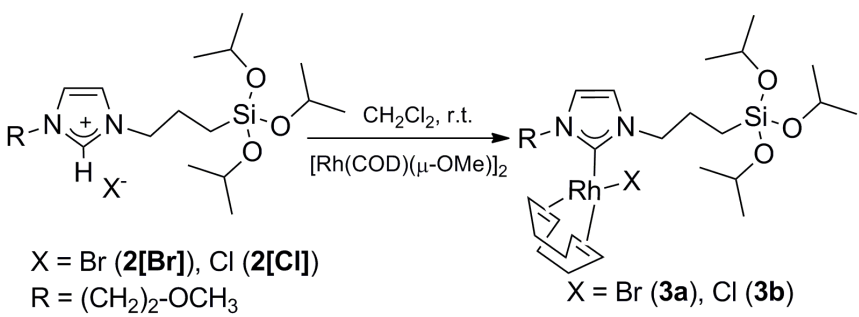

Scheme 2 .

Compounds $\mathbf{3} \mathbf{a}-\mathbf{b}$ were characterized by elemental analysis, mass spectrometry $\left(E S^{+}\right)$and ${ }^{1} \mathrm{H}$ and ${ }^{13} \mathrm{C}\left\{{ }^{1} \mathrm{H}\right\}$ NMR spectroscopy. Complex $\mathbf{3 b}$ was further characterized by $\mathrm{X}$-ray crystallography. A view of the molecular geometry of this compound is shown in Figure 1.

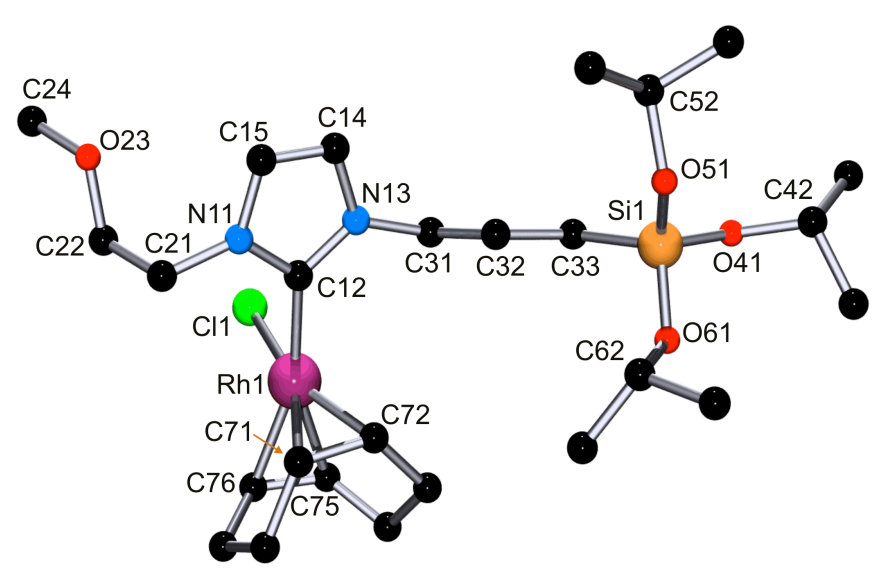

Figure 1. Molecular diagram of complex $3 \mathbf{b}$. Selected bond lengths $(\AA)$ and angles (deg) are: Rh1-Cl1, 2.4044(16); Rh1-C12, 2.033(7); Rh1-C71, 2.128(7); Rh1-C72, 2.099(7); Rh1-C75, 2.184(7); Rh1-C76, 2.193(7); Si1-C33, 1.845(7); Si1-O41, 1.618(5); Si1-O51, 1.610(6); Si1-O61, 1.634(6); C12-Rh1Cl1 88.4(2); N11-C12-N13, 105.0(6); N11-C12-Rh1, 127.0(5); N13-C12-Rh1, 127.7(5).

The rhodium atom (Rh1) displays a slightly distorted square planar coordination. The COD ligand chelates two of the coordination positions (av. Rh1-C(COD) distance, 2.15 $\AA$ ), while a chlorido ligand (Rh1-Cl1, 2.4044(16) $\AA$ ) and a carbon atom (C12) of the NHC ligand (Rh1-C12, 2.033(7) $\AA$ ) occupy the other two coordination sites. Considering the centroids of both $\mathrm{CH}=\mathrm{CH}$ bonds of COD as formally binding sites at Rh1, the angle of Rh1 with cis positioned atoms or centroids deviates less than $4^{\circ}$ from right angles (e.g., C12-Rh1-Cl1 88.4(2) $)^{\circ}$. Dihedral angle between the imidazole ring and the $\mathrm{Rh}$ coordination plane is $89.6(2)^{\circ}$. The geometry of the $\mathrm{Rh}^{\prime}(\mathrm{COD}) \mathrm{Cl}(\mathrm{NHC})$ fragment compares well with those reported for related complexes. ${ }^{[15]}$ Both substituents of the $\mathrm{N}$ atoms of the $\mathrm{NHC}$ ring are different, namely 2-methoxyethyl at $\mathrm{N} 11$, and $\left(\mathrm{CH}_{2}\right)_{3} \mathrm{Si}\left(\mathrm{O}^{\mathrm{i}} \mathrm{Pr}_{3}\right)_{3}$ at $\mathrm{N} 13$. In the latter, silicon binds to $\mathrm{C} 33$ of a methylene group and three additional oxygen atoms of the isopropoxy groups, displaying a typical tetrahedral geometry. As expected, the $\mathrm{Si} 1-\mathrm{C} 33$ distance $(1.845(7) \AA)$ is longer in comparison to $\mathrm{Si}-\mathrm{O}$ (Si1-O41,51,61 av., $1.62 \AA$ ).

The ${ }^{1} \mathrm{H}$ NMR spectra of complexes $\mathbf{3 a}$ and $\mathbf{3} \mathbf{b}$ show a typical pattern for the 2-methoxyethyl groups. ${ }^{[15 b]}$ The resonances due to 
the $-\left(\mathrm{CH}_{2}\right) \mathrm{Si}\left(\mathrm{O}^{\prime} \mathrm{Pr}\right)_{3}$ fragment compare well for both complexes and are slightly shifted to lower field than those observed in the ${ }^{1} \mathrm{H}$ NMR spectra of the corresponding imidazolium salts. The characteristic $\mathrm{CH}_{2} \mathrm{Si}$ resonance appears at around $\delta 0.75 \mathrm{ppm}$ and the resonances due to the isopropoxy group are observed at around $\delta 4.27 \mathrm{ppm}\left(\mathrm{CH}-{ }^{\mathrm{i}} \mathrm{PrO}\right)$ and $\delta 1.22 \mathrm{ppm}\left(\mathrm{CH}_{3}-{ }^{\mathrm{i}} \mathrm{PrO}\right)$. The ${ }^{13} \mathrm{C}\left\{{ }^{1} \mathrm{H}\right\}$ NMR spectra of complexes $\mathbf{3 a}$ and $\mathbf{3 b}$ exhibit a doublet resonance at around $\delta 183 \mathrm{ppm}\left({ }^{1} \mathrm{~J}_{\mathrm{Rh}-\mathrm{C}} \approx 51 \mathrm{~Hz}\right)$ which proves the coordination of the carbene ligand to the rhodium center. ${ }^{[15]}$ The olefinic carbon atoms of the COD ligand in complexes $\mathbf{3 a}$ and $\mathbf{3 b}$ feature three doublet resonances: one at $\delta 97.6 \mathrm{ppm}(3 \mathbf{a})$ and at $\delta$ $98.1 \mathrm{ppm}(\mathbf{3 b})\left(\mathrm{J}_{\mathrm{Rh}-\mathrm{C}} \approx 7 \mathrm{~Hz}\right)$ due the two olefinic carbon atoms situated trans to the carbene, and two at $\delta 68.6 \mathrm{ppm}$ and $\delta 68.4$ ppm (3a) and at $\delta 67.7 \mathrm{ppm}$ and $\delta 67.3 \mathrm{ppm}(3 \mathbf{b})\left(\mathrm{J}_{\mathrm{Rh}-\mathrm{C}} \approx 14 \mathrm{~Hz}\right)$, corresponding to the olefinic carbon atoms placed in relative cis position to the carbene ligand. ${ }^{[15]}$

Immobilization of $\mathbf{3 b}$ on MCM-41. The new material 3b-MCM-41 was prepared by refluxing a mixture of the $\mathrm{Rh}^{\prime}-\mathrm{NHC}$ complex $3 \mathbf{b}$ and MCM-41 (Mobil Composition of Matter $\mathrm{N}^{\circ} 41$ ) in toluene for $24 \mathrm{~h}$ (Scheme 3). ${ }^{[21]}$ The resulting off-white solid was characterized by elemental analysis, FT-IR, ${ }^{13} \mathrm{C},{ }^{29} \mathrm{Si}$ CP-MAS NMR and TEM.

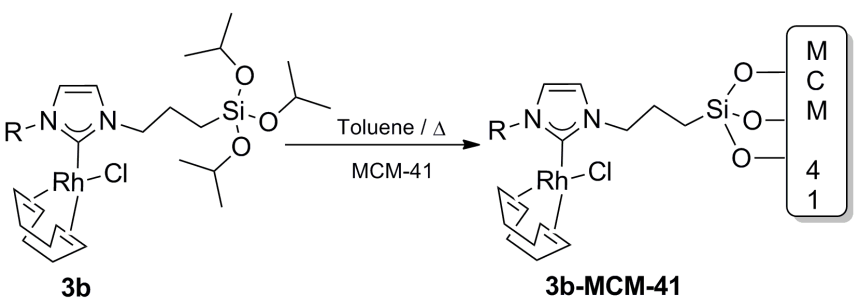

Scheme 3.

We have determined for 3b-MCM-41 a rhodium loading of 1.63 wt\% (Table 1) corresponding to $16.320 \mathrm{mg} / \mathrm{g}$ (this value corresponds to an average of two experiments). The FT-IR spectra of the new materials show the stretching vibration modes of the mesoporous framework (Si-O-Si) at around $1241 \mathrm{~cm}^{-1}$, $1043 \mathrm{~cm}^{-1}$ and $800 \mathrm{~cm}^{-1}$. 20] The FT-IR spectra of the grafted materials exhibit an additional broad absorption corresponding to the $v(\mathrm{C}=\mathrm{N})$ and $v(\mathrm{C}=\mathrm{C})$ stretching modes of the ligand at around $1630 \mathrm{~cm}^{-1}$. 21$]$

The resonances observed in the ${ }^{13} \mathrm{C} C P$-MAS solid state NMR spectra of 3b-MCM-41 compare well with those observed in the ${ }^{13} \mathrm{C}\left\{{ }^{1} \mathrm{H}\right\}$ NMR spectra of the parent complex $3 \mathbf{b}$. The ${ }^{13} \mathrm{C}$ CP-MAS solid state NMR spectra of $\mathbf{3 b}-\mathbf{M C M}-\mathbf{4 1}$ are dominated by aliphatic resonances. The most evident resonances are those corresponding to the $\mathrm{CH}_{\text {imd }}$ ( $\left.\delta 122.5 \mathrm{ppm}\right), \mathrm{CH}_{2} \mathrm{~N}(3)$ ( $\left.\delta 73.9 \mathrm{ppm}\right)$,

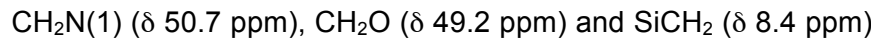
carbon atoms. The ${ }^{29} \mathrm{Si} \mathrm{CP-MAS} \mathrm{solid} \mathrm{state} \mathrm{NMR} \mathrm{spectra} \mathrm{of} \mathbf{3 b}$ MCM-41 exhibit resonances of great intensity corresponding to the silicon atoms of the parent MCM-41 (at around $-92.5 \mathrm{ppm}$ and $-100.6 \mathrm{ppm}$ ) and a less intense broad resonance at around $\delta-$ $57.5 \mathrm{ppm}$ assigned to the $\mathrm{CH}_{2} \mathrm{Si}$ silicon atom. As a whole, the above data confirm that complex $\mathbf{3 b}$ has been effectively immobilized on MCM-41.

In addition, the transmission electron microscopy (TEM) of $\mathbf{3 b -}$ MCM-41 evidences that the new material keeps the long-range ordering of hexagonal symmetry with regular, monodirectional channels of the parent MCM-41 (Figure 2).

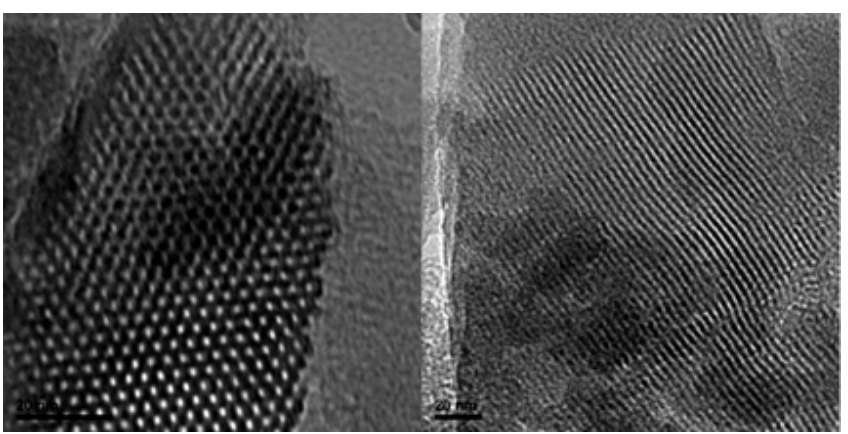

Figure 2. Transmission electron microscopy (TEM) of 3b-MCM-41.

The results of $\mathrm{N}_{2}$-physisorption/desorption studies of MCM-41 and the material $3 \mathrm{~b}-\mathrm{MCM}-\mathbf{4 1}$ including BET surface area, total pore volume, and BJH pore size are shown in table 1. These results indicate that the surface area, pore volume and pore diameter of 3b-MCM-41 decrease, and confirm the inclusion of the rhodium complex inside the channels of the mesoporous material.

\begin{tabular}{|lcccc|}
\hline \multicolumn{5}{|c|}{ Table 1. $\mathrm{N}_{2}$-physisorption/desorption studies. } \\
\hline Material & $\mathrm{Rh}(\mathrm{mg} / \mathrm{g})^{[\mathrm{a}]}$ & $\mathrm{S}_{\mathrm{BET}}\left(\mathrm{m}^{2} / \mathrm{g}\right)^{[\mathrm{b}]}$ & $\mathrm{Vp}\left(\mathrm{cm}^{3} / \mathrm{g}\right)^{[\mathrm{c}]}$ & $\mathrm{Dp}(\AA)^{[\mathrm{d}]}$ \\
\hline MCM-41 & - & 1731 & 1.41 & 27.6 \\
3b-MCM-41 & 16.32 & 1121 & 0.82 & 24.4 \\
\hline [a] ICP analysis. [b] surface area. [c] pore volume. [d] pore diameter.
\end{tabular}

Homogeneous versus heterogeneous catalytic hydrosilylation of acetophenone. 1,1,3,3,5,5hexamethyltrisiloxane (HexMTS) is a potential co-monomer for the preparation of poly(silyl ether)s. Thus, the choice of $1,1,1,3,5,5,5$-heptamethyltrisiloxane (HeptMTS) as hydrosilane for this catalytic study is justified by its analogy to HexMTS.

Treatment of acetophenone with HeptMTS at $80^{\circ} \mathrm{C}$ for $8 \mathrm{~h}$ using the rhodium chlorido species $\mathbf{3 b}$ or $\mathbf{3 b}-\mathbf{M C M}-\mathbf{4 1}$ as catalysts produces quantitatively the corresponding racemate $\mathrm{PhMeCH}-\mathrm{O}$ $\mathrm{SiMe}\left(\mathrm{OSiMe}_{3}\right)_{2}(4)$ (ee. $\approx 4 \%$ ) (Scheme 4, Table 2 entries 2-3). A decrease of the reaction yield was observed ( $86 \%$, Table 2 entry 1) when the rhodium bromido complex $3 \mathbf{a}$ is used as catalyst in accordance with a strong halide effect. ${ }^{[23]}$ Compound $\mathbf{4}$ has been isolated as a yellowish oil and characterized by mass spectrometry $\left(\mathrm{ES}^{+}\right),{ }^{1} \mathrm{H}$ and ${ }^{13} \mathrm{C}\left\{{ }^{1} \mathrm{H}\right\}$ NMR spectroscopy.<smiles>CC(=O)c1ccccc1</smiles><smiles>C[Si](O[SiH3])(O[SiH3])O[SiH3]</smiles><smiles>CO[Si](C)(OC)O[C@@H](C)c1ccccc1</smiles>

Scheme 4 . 


\begin{tabular}{|c|c|c|c|}
\hline Entry & Catalyst $^{[a]}$ & Yield $^{[b]}$ & cycles $^{[c]}$ \\
\hline 1 & $3 a$ & 86 & - \\
\hline 2 & $3 b$ & 100 & - \\
\hline 3 & $3 b-M C M-41$ & 100 & Fresh catalyst \\
\hline 4 & 3b-MCM-41 & 100 & 1 recycling \\
\hline 5 & $3 b-M C M-41$ & 100 & 2 recycling \\
\hline 6 & 3b-MCM-41 & 98 & 3 recycling \\
\hline 7 & MCM-41 & 0 & - \\
\hline
\end{tabular}

The recyclability of the heterogeneous catalyst 3b-MCM-41 was tested four times (fresh catalyst plus three cycles). The results showed in Table 2 (Entries 3 to 6) clearly indicate that the heterogeneous catalyst is reusable, and allow concluding that no significant leaching of the metal species takes place during the catalytic process. A blank reaction using commercial MCM-41 as catalyst (Table 2 , entry 7 ) showed no formation of 4 .

The catalytic reactions were monitored by Gas Chromatography (GC), the results of these studies are showed in Table 3 and Figure 3. In general, we have observed that the homogeneous catalyst $\mathbf{3 b}$ is the most active species (Table 3, entry 2). Interestingly, the heterogeneous catalyst $\mathbf{3 b}-\mathbf{M C M}-\mathbf{4 1}$ shows slightly lower activity (Table 3 , entry 3 ) than that observed for $\mathbf{3 b}$, and as it was expected, species 3 a (Table 3 , entry 1 ) is less active.

\begin{tabular}{|c|c|c|c|}
\hline \multicolumn{4}{|c|}{ Table 3. Catalytic hydrosilytation of acetophenone with HeptTMS } \\
Entry & Catalyst & $\operatorname{TOF}\left(\mathrm{h}^{-1}, 1 \mathrm{~h}\right)$ & $\operatorname{TOF}\left(\mathrm{h}^{-1}, 2 \mathrm{~h}\right)$ \\
\hline 1 & 3a & 22.0 & 11.4 \\
2 & 3b & 31.7 & 23.8 \\
3 & 3b-MCM-41 & 27.5 & 18.2 \\
\hline
\end{tabular}

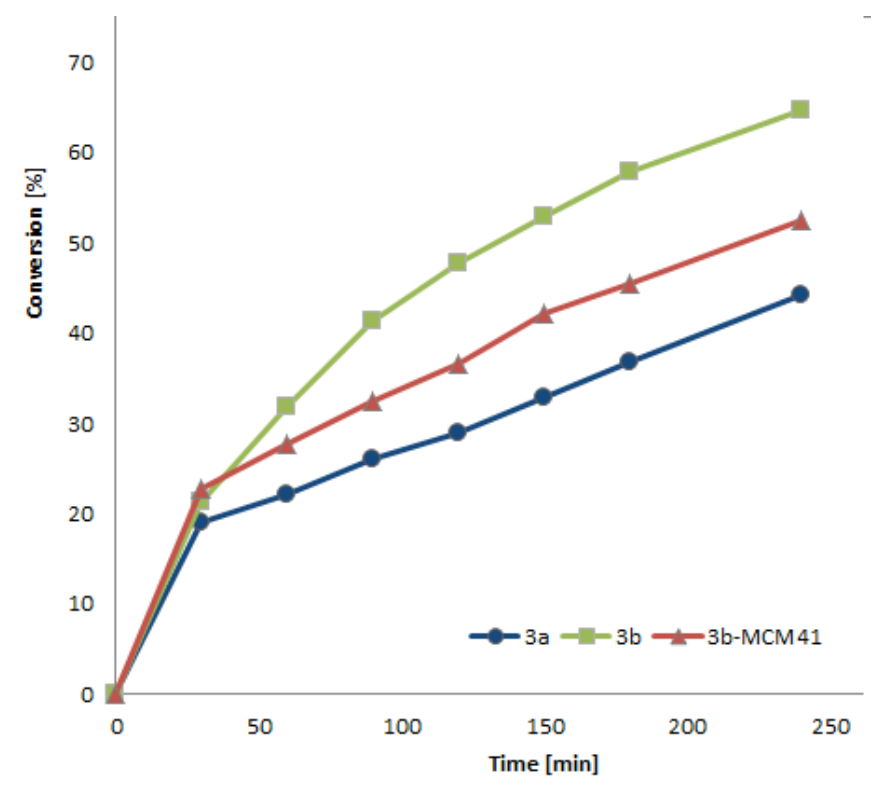

Figure 3. Time dependency of the conversion of acetophenone into $\mathbf{4}$ when the species $\mathbf{3 a}, \mathbf{3 b}$ or $\mathbf{3 b}-\mathbf{M C M}-\mathbf{4 1}(1.0 \% \mathrm{~mol})$ are used as catalysts.

${ }^{1} \mathrm{H}$ NMR studies of the reaction in $\mathrm{C}_{6} \mathrm{D}_{6}$, using $\mathbf{3 a}$ or $\mathbf{3 b}(10$ mol \%) as catalysts, confirm that it is necessary to overtake a previous activation step since no reaction was observed below 80 ${ }^{\circ} \mathrm{C}(3 \mathbf{a})$ or $60^{\circ} \mathrm{C}(\mathbf{3 b})$. These experiments showed complete conversion after $90 \mathrm{~min}$ at $80^{\circ} \mathrm{C}$ when $\mathbf{3 b}$ was used as catalyst. However, using $\mathbf{3 a}$ under the same reaction conditions only $10 \%$ of conversion was observed after $4 \mathrm{~h}$. In both cases, formation of mixtures of not identified $\mathrm{Rh}-\mathrm{H}$ containing species was observed.

These facts are in agreement with a reaction mechanism analogous to that reported by Ojima et al. (Scheme 5). ${ }^{[2]}$ The active catalyst, a rhodium(I)-hydride species, is generated by reaction of the corresponding rhodium(I) precursor with the silane. The halide effect, ${ }^{[23]}$ demonstrated by NMR studies and by the lower reaction yield achieved when rhodium(I)-bromido species $3 \mathbf{a}$ is used as catalyst precursor (Table 2 , entry 1 ), supports a higher activation barrier for the rhodium(I)-bromido complex in comparison with its chlorido counterpart. Once the active catalyst has been generated, a rhodium(III)-dihydride-silyl species is formed by oxidative addition of the silane to the rhodium center (Scheme 5). Then, a molecule of acetophenone coordinates to the metal center and subsequently inserts into the rhodium-silicon bond to afford a rhodium(III)-alkyl-hydride intermediate species which, by reductive elimination of $\mathbf{4}$, regenerates the rhodium(I)hydride active species. 


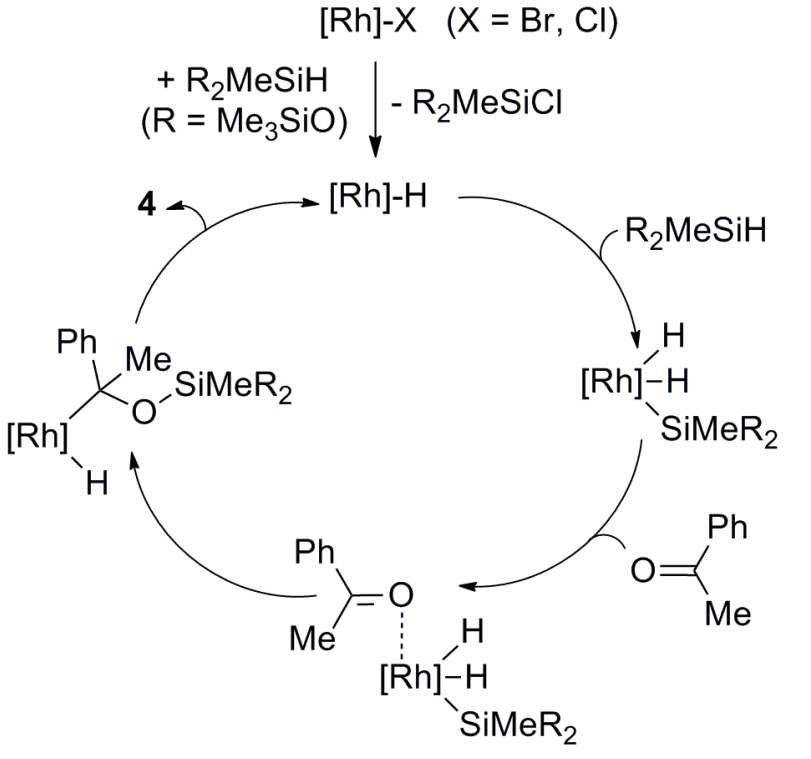

Scheme 5. Propossed mechanism for the hydrosilylation of acetophenone using $\mathbf{3 a}$ or $\mathbf{3 b}$ as catalyst.

Synthesis of poly(silyl ether)s by catalytic hydrosilylation. The results obtained for the hydrosilylation of acetophenone with HeptMTS prompted us to study the potential of species $\mathbf{3 b}$ and 3b-MCM-41 as catalyst precursors for the synthesis of poly(silylether)s by rhodium-catalysed hydrosilylation. The treatment of terephthalaldehyde with HexMTS in 1,4-dioxane at $110^{\circ} \mathrm{C}$ using the rhodium chlorido species $\mathbf{3 b}$ or $\mathbf{3 b}-\mathbf{M C M}-\mathbf{4} \mathbf{1}$ as catalysts affords quantitatively yellow oils which have been characterized by ${ }^{1} \mathrm{H},{ }^{13} \mathrm{C}\{1 \mathrm{H}\}$ and ${ }^{29} \mathrm{Si}$ NMR spectroscopy as the poly(silyl ether) 5 (Scheme 6).

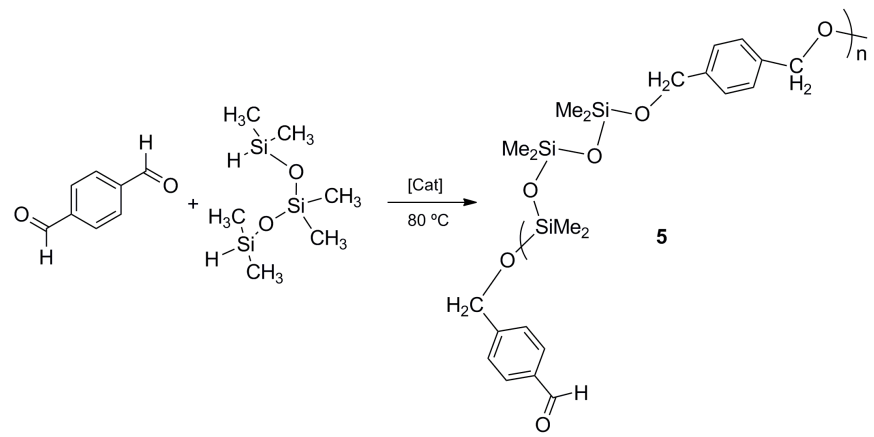

Scheme 6.

The ${ }^{1} \mathrm{H}$ NMR spectra of polymer 5 (Figure 4) are in agreement with the structure proposed in Scheme 6 . These spectra show four singlet resonances at $\delta 7.29 \mathrm{ppm}, \delta 4.75 \mathrm{ppm}, \delta 0.14 \mathrm{ppm}$ and $\delta 0.11 \mathrm{ppm}$ corresponding to the aromatic, $\mathrm{CH}_{2}$, $\mathrm{CH}_{2} \mathrm{OSi}\left(\mathrm{CH}_{3}\right)_{2}$ and $\mathrm{OSi}\left(\mathrm{CH}_{3}\right)_{2} \mathrm{O}$ protons, respectively. The presence of benzaldehyde end groups in $\mathbf{5}$ is evidenced by the resonance of the $\mathrm{CHO}$ proton at $\delta 10.0 \mathrm{ppm}$ and two doublets resonances at $\delta 7.84$ and $7.49 \mathrm{ppm}\left(\mathrm{J}_{\mathrm{HH}}=(8 \mathrm{~Hz})\right.$ corresponding to the $\mathrm{C}_{6} \mathrm{H}_{4}$ protons, marked as $\left(^{*}\right)$ in Figure 4 . The ${ }^{29} \mathrm{Si}\left\{{ }^{1} \mathrm{H}\right\} \mathrm{NMR}$ spectra of 5 in $\mathrm{CD}_{2} \mathrm{Cl}_{2}$ show two singlet resonances at $\delta-11.45$ ppm and at $\delta-20.82$ ppm corresponding to the $\mathrm{CH}_{2} \mathrm{OSi}$ and OSiO silicon atoms of the $-\mathrm{CH}_{2} \mathrm{OSiOSiOSiOCH} \mathrm{CH}_{2}$ - moiety, respectively.

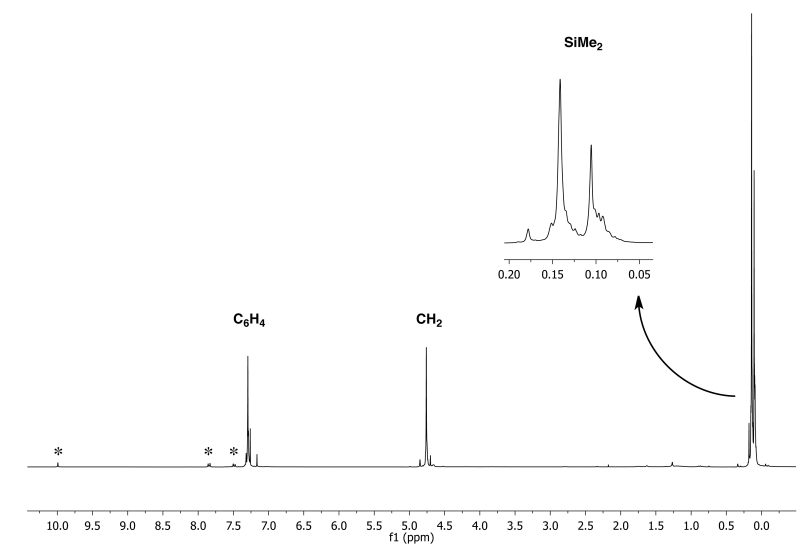

Figure 4. ${ }^{1} \mathrm{H}$ NMR spectrum of polymer 5 in $\mathrm{CD}_{2} \mathrm{Cl}_{2}$.

The weight-average molecular weight $\left(\mathrm{M}_{\mathrm{w}}\right)$ of polymer 5 depends on the catalytic system. The homogenous catalyst $\mathbf{3 b}$ gave a polymer with an average $M_{w}=5.184$ and a value of $M_{w} / M_{n}(P D I)$ $=1.7$. However, the freshly prepared heterogeneous catalyst $3 \mathbf{b}$ MCM-41 gave a polymer with a bimodal distribution. One corresponds to the $22 \% \mathrm{wt}$ of the total mass with an average $\mathrm{M}_{\mathrm{w}}=$ 93.970 and $\mathrm{PDI}=1.6$ and the other corresponding to the $78 \% \mathrm{wt}$ of the total mass, with a $\mathrm{M}_{\mathrm{w}}=7403$ and $\mathrm{PDI}=1.5$. Interestingly, the recyclability studies of catalyst $\mathbf{3 b}-\mathbf{M C M}-\mathbf{4 1}$ showed a drastic decrease of the average $M_{w}$ to values in the range of 3600-1600. It is remarkable that the PDI values for 5 are in the range of 1.71.5 , significantly lower than those reported for analogous copolymers prepared by Ru-catalysed hydrosilylation of terephthalaldehyde with 1,1,3,3-tretramethyldisiloxane $(\mathrm{PDI}=$ 2.74). ${ }^{[14]}$

The polymers obtained with catalyst $\mathbf{3 b}$ have a glass transition temperature $\left(T_{\mathrm{g}}\right)$ of $-87.5^{\circ} \mathrm{C}$. The TGA studies showed (Figure 5) that there is a complete destruction of the polymer at $452{ }^{\circ} \mathrm{C}$ with a weight loss of $98.3 \%$. Interestingly, the mixture of polymers obtained with the heterogeneous catalyst $\mathbf{3 b}-\mathbf{M C M}-\mathbf{4 1}$ has a $T_{\mathrm{g}}=$ $-85.1^{\circ} \mathrm{C}$. The TGA studies showed (Figure 5 ) a weigh loss of $48 \%$ at $420^{\circ} \mathrm{C}$ and an additional weight loss of $49 \%$ at $511^{\circ} \mathrm{C}$. It is worth mentioned that these $\mathrm{Tg}$ values are lower than those reported for analogous poly(silyl ether)s. ${ }^{[10,14]}$

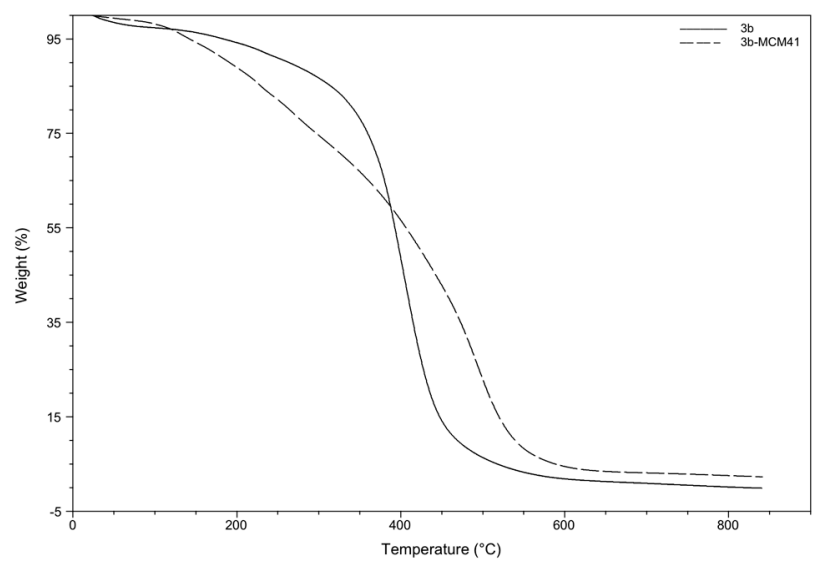

Figure 5. TGA analysis of samples of 5 obtained using $3 \mathrm{~b}$ or $\mathbf{3 b}-\mathbf{M C M}-\mathbf{4 1}$ as catalysts. 


\section{Conclusion}

The new rhodium(I) complexes [Rh(COD)(2-methoxyethyl-NHC$\left.\left.\left(\mathrm{CH}_{2}\right)_{3} \mathrm{Si}\left(\mathrm{O}^{i} \mathrm{Pr}_{3}\right)_{3}\right) \mathrm{X}\right](\mathrm{X}=\mathrm{Br}(\mathbf{3 a}), \mathrm{Cl}(\mathbf{3 b}))$ have been synthesized and fully characterized. The study of their application as ketone hydrosilylation catalysts showed a clear halide effect, being the chlorido species $\mathbf{3 b}$ more active than the bromido derivative $\mathbf{3 a}$ The most active species $\mathbf{3 b}$ has been immobilized on MCM- 41 to afford 3b-MCM-41. The new material 3b-MCM-41 has been fully characterized. A comparative catalytic study indicates that $\mathbf{3 b}$ and 3b-MCM-41 are effective catalysts for the hydrosilylation of acetophenone and, moreover the heterogeneous catalyst $\mathbf{3 b}$ MCM-41 can be reutilized. Both species are also active for the preparation of poly(silyl ether)s, with a low PDI (1.7-1.5), by rhodium(I)-catalysed hydrosilylation of terephthalaldehyde. The copolymers with higher $\mathrm{M}_{\mathrm{w}}$ were obtained using $\mathbf{3 b}-\mathbf{M C M}-\mathbf{4 1}$ as catalyst. Further investigations regarding the design of more active catalyst for the preparation of poly(silyl ether)s are in progress.

\section{Experimental Section}

General information. All manipulations were performed with rigorous exclusion of air at an argon/vacuum manifold using standard Schlenktube techniques or in a dry-box (MB-UNILAB). Solvents were dried by the usual procedures and distilled under argon prior to use or taken under argon from a Solvent Purification System (SPS). (3Bromopropyl)trichlorosilane, 4-dimethylaminopyridine, Dowex® 1X8100 chlorido form resin, acetophenone, 1,1,1,3,5,5,5 heptamethyltrisiloxane, mesytilene, 1,1,3,3,5,5-hexamethyltrisiloxane and terephthalaldehyde were purchased from commercial sources and used without further purifications. The starting material $[\mathrm{Rh}(\mathrm{COD})(u-\mathrm{OMe})]_{2}$ was prepared according with methods reported in the literature. ${ }^{[25]}$ NMR spectra were recorded on a Varian Gemini 2000, Bruker ARX 300, Bruker Avance $300 \mathrm{MHz}$ or Bruker Avance $400 \mathrm{MHz}$ instrument. Chemical shifts (expressed in parts per million) are referenced to residual solvent peaks $\left({ }^{1} \mathrm{H},{ }^{13} \mathrm{C}\left\{{ }^{1} \mathrm{H}\right\}\right)$. Coupling constants, J, are given in hertz. $\mathrm{C}, \mathrm{H}$, and $\mathrm{N}$ analyses were carried out in a Perkin-Elmer $2400 \mathrm{CHNS} / \mathrm{O}$ analyzer. Mass spectroscopy was measured on an Esquire 3000+ with Ion trap detector interfaced to an Agilent 1100 series HPLC system. FT-IR spectra were recorded on a Nicolet Nexus 5700 FT spectrophotometer equipped with a Nicolet Smart Collector diffuse reflectance accessory. Gas chromatography analyses were performed using an Agilent 6890N with FID detector equipped with a HP-1 column from J\&W Scientific $(30 \mathrm{~m}, 0.25 \mathrm{~mm}$ i.d.). Parameters were as follows: Initial temperature $50{ }^{\circ} \mathrm{C}$, initial time $5 \mathrm{~min}$, ramp $30^{\circ} \mathrm{C} / \mathrm{min}$, final temperature $250{ }^{\circ} \mathrm{C}$, final time $5 \mathrm{~min}$, injector temperature $250{ }^{\circ} \mathrm{C}$, detector temperature $300{ }^{\circ} \mathrm{C}$. TEM microscopy images were collected with a INCA $200 \mathrm{X}$ Sight from Oxford Instruments with a resolution in energy between $136 \mathrm{eV}$ and $5.9 \mathrm{KeV}$. Isotherms were obtained on a Quantachrome AUTOSORB by measuring the volume of $\mathrm{N}_{2}$ absorbed at relative pressures between 0.05 and 0.99 at $77.3 \mathrm{~K}$ after drying the sample at $120{ }^{\circ} \mathrm{C}$ in vacuo. Absolute Molecular weights of polymers were determined by GPC-MALS. Before injection all samples were filtered through $0.45 \mathrm{~mm}$ PTFE membranes. The column oven temperature was maintained at $35{ }^{\circ} \mathrm{C}$ during all the experiments. The measurements were carried out on a Waters 2695 autosampler equipped with three in line PLGel Mixed C $(7.8 \times 300 \mathrm{~mm})$ columns and a Wyatt three detector setup (Minidaw TREOS ${ }^{\circledR}$ (MALS), Optilab $\operatorname{Rex}^{\circledR}$ (DRI) and VIscostarlI ${ }^{\circledR}$ Viscometer). The samples were eluted with THF at a rate of $1 \mathrm{~mL} / \mathrm{min}$. TGA of the polymers was measured on a TA Instruments SDT 2960 at a flow rate of $40 \mathrm{~cm}^{3}$ of nitrogen per min. The temperature program was $10^{\circ} \mathrm{C} / \mathrm{min}$ from 25 to $850{ }^{\circ} \mathrm{C}$. $\mathrm{Tg}$ of the polymer was determined by DSC on a TA instruments DSC Q1000 with liquid nitrogen cooling system. The temperature program for the analysis was begun at $-120{ }^{\circ} \mathrm{C}$ and the temperature was increased at a rate of $10^{\circ} \mathrm{C} / \mathrm{min}$ to $25^{\circ} \mathrm{C}$.
X-ray crystal data for 3b were recorded at $100 \mathrm{~K}$ with a Bruker Kappa APEX2 diffractometer equipped with an area detector and graphite monochromated Mo Ka radiation $(0.71073 \AA)$. Data reduction was done with the APEX2 software. ${ }^{[26]}$ The structure was solved by direct methods and refined by full-matrix least-squares methods based on $F^{2}$ using SHELXL-97 and WinGX programs. ${ }^{[27]}$ Non-hydrogen atoms were refined anisotropically, while hydrogen atoms were positioned geometrically and refined with isotropic displacement parameters according to the riding model. Distance and angle calculations were performed using the SHELXL-97 and WinGX programs. ${ }^{[27]}$ Refinement parameters are as follows: $\left[\mathrm{C}_{26} \mathrm{H}_{48} \mathrm{CIN}_{2} \mathrm{O}_{4} \mathrm{RhSi}\right.$ (3b), triclinic, $P-1, a=9.9500(18) \AA, b=13.003(2) \AA, c=13.349(2) \AA, \alpha=$ 107.377(2) ${ }^{\circ}, \beta=103.957(2)^{\circ}, \gamma=105.201(2)^{\circ}, Z=2, M_{r}=619.11 \mathrm{~g}$ $\mathrm{mol}^{-1}, V=1491.8(5) \AA^{3}, D_{\text {calcd }}=1.378 \mathrm{~g} \mathrm{~cm}^{-3}, \lambda($ Mo Ka $)=0.71073 \AA$, $\mathrm{T}=100 \mathrm{~K}, \mu=0.734 \mathrm{~mm}^{-1}, 11827$ reflections collected, 5967 observed $\left(R_{\text {int }}=0.064\right), R 1\left(F_{\mathrm{o}}\right)=0.0778[I>2 \sigma(I)], w R 2\left(F_{\mathrm{o}}{ }^{2}\right)=$ 0.1503 (all data), GOF = 1.096. CCDC: 879869 .

Preparation of 1-(2-methoxyethyl)-2H-imidazole (1): $\mathrm{NaOH}$ (1.28 g, $320 \mathrm{mmol}$ ) was added to an acetonitrile $(30 \mathrm{~mL})$ solution of imidazole $(1.088 \mathrm{~g}, 16.0 \mathrm{mmol})$ and the mixture was refluxed for $30 \mathrm{~min}$. After that, 2-chloroethylmethylether $(1.5 \mathrm{~mL}, 16.0 \mathrm{mmol})$ was added dropwise to the solution and the mixture refluxed for $16 \mathrm{~h}$. The solution was filtered and the solvent was removed in vacuo. The oily residue was extracted with $\mathrm{Et}_{2} \mathrm{O}(3 \times 20 \mathrm{~mL})$ and the solvent was removed in vacuo to afford yellowish oil. Yield 1,88 g (93\%). ${ }^{1} \mathrm{H}$ NMR (300 MHz, $\mathrm{CDCl}_{3}, 293 \mathrm{~K}$ ): $\delta 7.50$ (s, 1H, NCHN), 7.03 (vt, 1H, J $\mathrm{H}_{-\mathrm{H}}=1$ $\left.\mathrm{Hz}, \mathrm{CH}_{\text {imd }}\right), 6.95\left(\mathrm{vt}, 1 \mathrm{H}, J_{\mathrm{H}-\mathrm{H}}=1 \mathrm{~Hz}, \mathrm{CH}_{\text {imd }}\right), 4.07\left(\mathrm{t}, 2 \mathrm{H}, J_{\mathrm{H}-\mathrm{H}}=5 \mathrm{~Hz}\right.$, $\left.\mathrm{CH}_{2} \mathrm{~N}\right), 3.61\left(\mathrm{t}, 2 \mathrm{H}, J_{\mathrm{H}-\mathrm{H}}=5 \mathrm{~Hz}, \mathrm{CH}_{2} \mathrm{O}\right), 3.32\left(\mathrm{~s}, 3 \mathrm{H}, \mathrm{CH}_{3} \mathrm{O}\right) .{ }^{13} \mathrm{C} \mathrm{NMR}$ $\left(75 \mathrm{MHz}, \mathrm{CDCl}_{3}, 293 \mathrm{~K}\right): \delta 137.5(\mathrm{NCHN}), 129.3\left(\mathrm{CH}_{\text {imd }}\right), 119.1$ $\left(\mathrm{CH}_{\mathrm{imd}}\right), 71.9\left(\mathrm{CH}_{2} \mathrm{O}\right), 59.1\left(\mathrm{CH}_{3} \mathrm{O}\right), 47.1\left(\mathrm{CH}_{2} \mathrm{~N}\right)$.

Preparation of $\mathrm{Br}\left(\mathrm{CH}_{2}\right)_{3} \mathrm{Si}\left({ }^{\mathrm{i}} \mathrm{PrO}\right)_{3}$ : To a solution of 1,8Bis(dimethylamino)pyridine $(3.20 \mathrm{~g}, 14.5 \mathrm{mmol})$ in ${ }^{\mathrm{i}} \mathrm{PrOH}(40 \mathrm{~mL})$ $\mathrm{Br}\left(\mathrm{CH}_{2}\right)_{3} \mathrm{SiCl}_{3}(0.75 \mathrm{~mL}, 4.8 \mathrm{mmol})$ was added dropwise at $0{ }^{\circ} \mathrm{C}$. The resulting mixture was warmed to r.t. and stirred during $10 \mathrm{~h}$ to give a white suspension. The ${ }^{\mathrm{i}} \mathrm{PrOH}$ solution was filtered and the solvent removed in vacuo to afford a white oily residue which was extracted with hexane $(2 \times 20 \mathrm{~mL})$. The solvent was removed in vacuo to give a pale yellow liquid. Yield $1.40 \mathrm{~g},(89 \%) .{ }^{1} \mathrm{H} \mathrm{NMR}\left(300 \mathrm{~Hz}, \mathrm{CDCl}_{3}, 293\right.$ $\mathrm{K})$ : $\delta 4.19\left(\mathrm{stp}, 6 \mathrm{H}, \mathrm{J}_{\mathrm{H}-\mathrm{H}}=7 \mathrm{~Hz}, \mathrm{CH}\right.$ - $\left.\mathrm{PrO}\right), 3.40\left(\mathrm{t}, 2 \mathrm{H}, \mathrm{J}_{\mathrm{H}-\mathrm{H}}=7 \mathrm{~Hz}\right.$, $\left.\mathrm{CH}_{2} \mathrm{Br}\right), 1.94\left(\mathrm{~m}, 2 \mathrm{H},-\mathrm{CH}_{2}-\right), 1.17\left(\mathrm{~d}, 18 \mathrm{H}, \mathrm{J}_{\mathrm{H}-\mathrm{H}}=6 \mathrm{~Hz}, \mathrm{CH}_{3}-{ }^{\mathrm{i}} \mathrm{PrO}\right)$, $0.69\left(\mathrm{~m}, 2 \mathrm{H}, \mathrm{CH}_{2} \mathrm{Si}\right) .{ }^{13} \mathrm{C}\left\{{ }^{1} \mathrm{H}\right\}$ NMR $\left(300 \mathrm{MHz} \mathrm{CDCl}_{3}, 293 \mathrm{~K}\right): \delta 65.0$ ( $\mathrm{CH}-\mathrm{i} \mathrm{PrO}), 36.9\left(\mathrm{CH}_{2} \mathrm{Br}\right), 26.9\left(-\mathrm{CH}_{2}{ }^{-}\right), 25.5$ (s, $\left.\mathrm{CH}_{3}{ }^{-} \mathrm{PrO}\right), 11.2$ (s, $\left.\mathrm{CH}_{2} \mathrm{Si}\right)$. MS (ESI $)$ : m/z $248.3\left(\mathrm{M}^{+}\right)$.

Preparation of 1-(3-triisopropoxysilylpropyl)-3-(2-methoxy-ethyl)Imidazolium bromide ([2]Br): To an acetonitrile $(30 \mathrm{~mL})$ solution of 2methoxy-ethyl imidazole $(0.31 \mathrm{~g}, 2.5 \mathrm{mmol}) \mathrm{Br}\left(\mathrm{CH}_{2}\right)_{3} \mathrm{Si}\left({ }^{i} \mathrm{PrO}\right)_{3}(0.98 \mathrm{~g}$, $3.0 \mathrm{mmol}$ ) was added. The reaction mixture was stirred at $90{ }^{\circ} \mathrm{C}$ for $24 \mathrm{~h}$. The solution was filtered through Celite and the solvent was removed in vacuo. The residue thus obtained was washed with hexane $(2 \times 20 \mathrm{~mL})$ to give an off-white oily solid. Yield $0.94 \mathrm{~g}(84 \%)$. Anal. Calcd for $\mathrm{C}_{18} \mathrm{H}_{37} \mathrm{BrN}_{2} \mathrm{O}_{4} \mathrm{Si}$ : C, 47.67, $\mathrm{H}, 8.22, \mathrm{~N}, 6.18$. Found: C, 47.91, $\mathrm{H}, 8.35, \mathrm{~N}, 6.58$. ${ }^{1} \mathrm{H}$ NMR plus $\mathrm{COSY}\left(300 \mathrm{MHz}, \mathrm{CDCl}_{3}, 293\right.$ $\mathrm{K}): \delta 10.12(\mathrm{~s}, 1 \mathrm{H}, \mathrm{NCHN}), 7.60\left(\mathrm{~m}, 1 \mathrm{H}, \mathrm{CH}_{\text {imd }}\right), 7.29(\mathrm{~m}, 1 \mathrm{H}, \mathrm{Hz}$, $\mathrm{CH}_{\text {imd }}$ ), $4.60\left(\mathrm{vt}, 2 \mathrm{H}, \mathrm{J}_{\mathrm{H}-\mathrm{H}}=5, \mathrm{CH}_{2} \mathrm{~N}^{(3)}\right), 4.27\left(\mathrm{vt}, 2 \mathrm{H}, \mathrm{J}_{\mathrm{H}-\mathrm{H}}=7, \mathrm{CH}_{2} \mathrm{~N}^{(1)}\right.$ ), 4.15 (spt, $\left.3 \mathrm{H}, J_{\mathrm{H}-\mathrm{H}}=6, \mathrm{CH}-\mathrm{PrO}\right), 3.74\left(\mathrm{vt}, 2 \mathrm{H}, \mathrm{J}_{\mathrm{H}-\mathrm{H}}=5, \mathrm{CH}_{2} \mathrm{O}\right), 3.32$ (s $\left.3 \mathrm{H}, \mathrm{OCH}_{3}\right), 1.95\left(\mathrm{~m}, 2 \mathrm{H},-\mathrm{CH}_{2}\right)^{-}, 1.13\left(\mathrm{~d}, 18 \mathrm{H}, \mathrm{J}_{\mathrm{H}-\mathrm{H}}=6 \mathrm{~Hz}, \mathrm{CH}_{3}-\mathrm{PrO}\right)$, $0.50\left(\mathrm{~m}, 2 \mathrm{H}, \mathrm{CH}_{2} \mathrm{Si}\right) .{ }^{13} \mathrm{C}\left\{{ }^{1} \mathrm{H}\right\}$ NMR plus HSQC $\left(75.46 \mathrm{MHz}, \mathrm{CDCl}_{3}\right.$, $293 \mathrm{~K})$ : $\delta 137.4(\mathrm{NCHN}), 123.4\left(\mathrm{CH}_{\mathrm{imd}}\right), 121.3\left(\mathrm{CH}_{\mathrm{imd}}\right), 70.4\left(\mathrm{CH}_{2} \mathrm{O}\right)$, $65.4(\mathrm{CH}-\mathrm{i} \mathrm{PrO}), \quad 59.0\left(\mathrm{OCH}_{3}\right), 51.8\left(\mathrm{CH}_{2} \mathrm{~N}^{(1)}\right), 49.9\left(\mathrm{CH}_{2} \mathrm{~N}^{(3)}\right), 25.6$ $\left(\mathrm{CH}_{3}{ }^{-} \mathrm{PrO}\right), 24.6\left(-\mathrm{CH}_{2}{ }^{-}\right), 8.6\left(\mathrm{CH}_{2} \mathrm{Si}\right) . \mathrm{MS}\left(\mathrm{ESI}^{+}\right)$: $\mathrm{m} / \mathrm{z} 373.2\left(\mathrm{M}^{+}-\mathrm{Br}\right)$.

Preparation of 1-(3-triisopropoxysilylpropyl)-3-(2-methoxy-ethyl)Imidazolium chloride ([2]Cl): A dichlorometane $(5.0 \mathrm{~mL})$ solution of [2] $\mathrm{Br}(0.45 \mathrm{~g}, 1.00 \mathrm{mmol})$ was passed through an ion exchange column packed with Dowex® $1 \times 8-100$ chloride form resin. The solvent was removed in vacuo and the oily residue washed with hexane $(20 \mathrm{~mL})$ to give an off-white oily solid. Yield $0.41 \mathrm{~g}(91 \%)$. Anal. Calcd for $\mathrm{C}_{18} \mathrm{H}_{37} \mathrm{CIN}_{2} \mathrm{O}_{4} \mathrm{Si}$ : C, 52.85, H, 9.12, N, 6.85. Found: C, 
52.56, H, 9.60, N, 6.58. ${ }^{1} \mathrm{H}$ NMR plus COSY $\left(300 \mathrm{MHz}, \mathrm{CDCl}_{3}, 293\right.$ $\mathrm{K}): \delta 10.24(\mathrm{~s}, 1 \mathrm{H}, \mathrm{NCHN}), 7.67$ (s, $\left.1 \mathrm{H}, \mathrm{CH}_{\text {imd }}\right), 7.35$ (s, $1 \mathrm{H}, \mathrm{CH}_{\text {imd }}$ ) $4.64\left(\mathrm{t}, 2 \mathrm{H}, \mathrm{J}_{\mathrm{H}-\mathrm{H}}=5 \mathrm{~Hz}, \mathrm{CH}_{2} \mathrm{~N}^{(3)}\right), 4.31\left(\mathrm{t}, 2 \mathrm{H}, \mathrm{J}_{\mathrm{H}-\mathrm{H}}=7 \mathrm{~Hz}, \mathrm{CH}_{2} \mathrm{~N}^{(1)}\right.$ ), 4.19 (spt, $\left.3 \mathrm{H}, J_{\mathrm{H}-\mathrm{H}}=6 \mathrm{~Hz}, \mathrm{CH}-\mathrm{PrO}\right), 3.78\left(\mathrm{t}, 2 \mathrm{H}, \mathrm{J}_{\mathrm{H}-\mathrm{H}}=5 \mathrm{~Hz}, \mathrm{CH}_{2} \mathrm{O}\right.$ ), $3.35\left(\mathrm{~s}, 3 \mathrm{H}, \mathrm{CH}_{3} \mathrm{O}\right), 1.99\left(\mathrm{~m}, 2 \mathrm{H},-\mathrm{CH}_{2}-\right), 1.17\left(\mathrm{~d}, 18 \mathrm{H}, \mathrm{J}_{\mathrm{H}-\mathrm{H}}=6 \mathrm{~Hz}\right.$ $\left.\mathrm{CH}_{3}{ }^{\mathrm{i}} \mathrm{PrO}\right), 0.54\left(\mathrm{~m}, 2 \mathrm{H}, \mathrm{CH}_{2} \mathrm{Si}\right) .{ }^{13} \mathrm{C}$ NMR plus HSQC $\left(75 \mathrm{MHz}, \mathrm{CDCl}_{3}\right.$ $293 \mathrm{~K}) \delta 140.4(\mathrm{NCHN}), 123.3\left(\mathrm{CH}_{\text {imd }}\right), 121.0\left(\mathrm{CH}_{\text {imd }}\right), 70.7\left(\mathrm{CH}_{2} \mathrm{O}\right)$, $65.5(\mathrm{CH}-\mathrm{PrO}), 59.1\left(\mathrm{CH}_{3} \mathrm{O}\right), 51.8\left(\mathrm{CH}_{2} \mathrm{~N}^{(1)}\right), 49.9\left(\mathrm{CH}_{2} \mathrm{~N}^{(3)}\right), 25.7$ ( $\left.\mathrm{CH}_{3}{ }^{-} \mathrm{PrO}\right), 24.7\left(-\mathrm{CH}_{2}{ }^{-}\right), 8.5\left(\mathrm{CH}_{2} \mathrm{Si}\right)$. MS $\left(\mathrm{ESI}^{+}\right)$: m/z $373.3\left(\mathrm{M}^{+}-\mathrm{Cl}\right)$.

Preparation of (3a): $\mathrm{CH}_{2} \mathrm{Cl}_{2}(30 \mathrm{~mL})$ was added to a mixture of [2] $\mathrm{Br}$ $(0.45 \mathrm{~g}, 1.0 \mathrm{mmol})$ and $[\mathrm{Rh}(\mathrm{COD})(\mu-\mathrm{OMe})]_{2}(0.24 \mathrm{~g}, 0.5 \mathrm{mmol})$. The reaction mixture was stirred at room temperature for $10 \mathrm{~h}$. The solvent was removed in vacuo and the residue thus obtained extracted with hexane $(2 \times 20 \mathrm{~mL})$ and washed with pentane $(2 \times 10 \mathrm{~mL})$ to afford a yellow crystalline solid. Yield $0.62 \mathrm{~g}(93 \%)$. Anal. Calcd for $\mathrm{C}_{26} \mathrm{H}_{48} \mathrm{BrN}_{2} \mathrm{O}_{4} \mathrm{RhSi}: \mathrm{C}, 47.06, \mathrm{H}, 7.29, \mathrm{~N}, 4.22$. Found: $\mathrm{C}, 46.96, \mathrm{H}$ 7.24, N, 4.21. ${ }^{1} \mathrm{H}$ NMR $\left(400 \mathrm{MHz}, \mathrm{C}_{6} \mathrm{D}_{6}, 298 \mathrm{~K}\right): \delta 6.67\left(\mathrm{~d}, 1 \mathrm{H}, \mathrm{J}_{\mathrm{H}-\mathrm{H}}=2\right.$ $\left.\mathrm{Hz}, \mathrm{CH}_{\text {imd }}\right), 6.30\left(\mathrm{~d}, 1 \mathrm{H}, J_{\mathrm{H}-\mathrm{H}}=2 \mathrm{~Hz}, \mathrm{CH}_{\text {imd }}\right), 5.50\left(\mathrm{~s}, 2 \mathrm{H}, \mathrm{CH}_{\mathrm{COD}}\right), 4.86$ (ddd, $1 \mathrm{H}, J_{\mathrm{H}-\mathrm{H}}=14 \mathrm{~Hz}, J_{\mathrm{H}-\mathrm{H}}=5 \mathrm{~Hz}, J_{\mathrm{H}-\mathrm{H}}=3.5 \mathrm{~Hz}, \mathrm{CH}_{2} \mathrm{O}$ ), 4.58 (ddd, $1 \mathrm{H}$, $\left.J_{H-H}=13 \mathrm{~Hz}, J_{\mathrm{H}-\mathrm{H}}=9 \mathrm{~Hz}, J_{\mathrm{H}-\mathrm{H}}=6 \mathrm{~Hz}, \mathrm{CH}_{2} \mathrm{~N}^{(1)}\right), 4.28\left(\mathrm{spt}, 3 \mathrm{H}, J_{\mathrm{H}-\mathrm{H}}=6 \mathrm{~Hz}\right.$, $\mathrm{CH}$-'PrO), $4.25-4.12\left(\mathrm{~m}, 1 \mathrm{H}, \mathrm{CH}_{2} \mathrm{~N}^{(1)} ; 1 \mathrm{H}, \mathrm{CH}_{2} \mathrm{O}\right.$ ), 3.75 (ddd, $1 \mathrm{H}, \mathrm{J}_{\mathrm{H}}$ $\left.\mathrm{H}=10 \mathrm{~Hz}, J_{\mathrm{H}-\mathrm{H}}=9 \mathrm{~Hz}, J_{\mathrm{H}-\mathrm{H}}=3.5 \mathrm{~Hz}, \mathrm{CH}_{2} \mathrm{~N}^{(3)}\right), 3.52$ (ddd, $1 \mathrm{H}, J_{\mathrm{H}-\mathrm{H}}=10$ $\left.\mathrm{Hz}, J_{\mathrm{H}-\mathrm{H}}=9 \mathrm{~Hz}, J_{\mathrm{H}-\mathrm{H}}=3.5 \mathrm{~Hz}, \mathrm{CH}_{2} \mathrm{~N}^{(3)}\right), 3.31\left(\mathrm{~m}, 2 \mathrm{H}, \mathrm{CH}_{\mathrm{COD}}\right), 2.98(\mathrm{~s}$, $\left.3 \mathrm{H}, \mathrm{CH}_{3} \mathrm{O}\right), 2.41-2.13\left(\mathrm{~m}, 4 \mathrm{H}, \mathrm{CH}_{2 \mathrm{COD}} ; 1 \mathrm{H},-\mathrm{CH}_{2}-\right), 2.05(\mathrm{~m}, 1 \mathrm{H}$, $\left.\mathrm{CH}_{2}-\right), 1.77\left(\mathrm{~m}, 4 \mathrm{H}, \mathrm{CH}_{2 \mathrm{COD}}\right), 1.23\left(\mathrm{vdd}, 18 \mathrm{H}, \mathrm{J}_{\mathrm{H}-\mathrm{H}}=6 \mathrm{~Hz}, \mathrm{~J}_{\mathrm{H}-\mathrm{H}}=3 \mathrm{~Hz}\right.$, $\left.\mathrm{CH}_{3}-\mathrm{P} \mathrm{PrO}\right), 0.75\left(\mathrm{~m}, 2 \mathrm{H}, \mathrm{CH}_{2} \mathrm{Si}\right) .{ }^{13} \mathrm{C}\left\{{ }^{1} \mathrm{H}\right\}$ NMR $\left(101 \mathrm{MHz}, \mathrm{C}_{6} \mathrm{D}_{6}, 293\right.$ $\mathrm{K}): \delta 183.0\left(\mathrm{~d}, J_{\mathrm{Rh}-\mathrm{C}}=51 \mathrm{~Hz}, \mathrm{RhC} C_{\text {Carbene }}\right), 122.0\left(\mathrm{CH}_{\text {imd }}\right), 120.0\left(\mathrm{CH}_{\text {imd }}\right)$, $97.6\left(\mathrm{~d}, J_{\mathrm{Rh}-\mathrm{C}}=7 \mathrm{~Hz}, 2 \mathrm{C}, \mathrm{CH}_{\mathrm{COD}}\right), 72.2\left(\mathrm{CH}_{2} \mathrm{~N}^{(3)}\right), 68.6\left(\mathrm{~d}, \mathrm{~J}_{\mathrm{Rh}-\mathrm{C}}=14 \mathrm{~Hz}\right.$ $\left.\mathrm{CH}_{\text {COD }}\right), 68.4\left(\mathrm{~d}, \mathrm{~J}_{\mathrm{Rh}-\mathrm{C}}=14 \mathrm{~Hz}, \mathrm{CH}_{\mathrm{COD}}\right), 65.3(\mathrm{CH}-\mathrm{PrO}), 58.6\left(\mathrm{CH}_{3} \mathrm{O}\right)$, $53.4\left(\mathrm{CH}_{2} \mathrm{~N}^{(1)}\right), 50.9\left(\mathrm{CH}_{2} \mathrm{O}\right), 33.3\left(\mathrm{CH}_{2 \mathrm{COD}}\right), 33.0\left(\mathrm{CH}_{2 \mathrm{COD}}\right), 29.7$ $\left(\mathrm{CH}_{2 \mathrm{COD}}\right), 29.5\left(\mathrm{CH}_{2 \mathrm{COD}}\right), 25.9\left(\mathrm{CH}_{3}{ }^{\mathrm{i}} \mathrm{PrO}\right), 25.2\left(-\mathrm{CH}_{2}{ }^{-}\right), 10.0\left(\mathrm{CH}_{2} \mathrm{Si}\right)$. MS $\left(\mathrm{ESI}^{+}\right): \mathrm{m} / \mathrm{z} 583.1\left(\mathrm{M}^{+}\right)$.

Preparation of (3b): $\mathrm{CH}_{2} \mathrm{Cl}_{2}(30 \mathrm{~mL})$ was added to a mixture of [2] Cl $(0.41 \mathrm{~g}, 1.0 \mathrm{mmol})$ and $[\mathrm{Rh}(\mathrm{COD})(\mathrm{u}-\mathrm{OMe})]_{2}(0.24 \mathrm{~g}, 0.5 \mathrm{mmol})$. The reaction mixture was stirred at room temperature for $10 \mathrm{~h}$. The solvent was removed in vacuo and the residue thus obtained extracted with hexane $(2 \times 20 \mathrm{~mL})$ and washed with pentane $(2 \times 10 \mathrm{~mL})$ to afford a yellow crystalline solid. Yield $0.54 \mathrm{~g}(87 \%)$. Anal. Calcd for $\mathrm{C}_{26} \mathrm{H}_{48} \mathrm{CIN}_{2} \mathrm{O}_{4} \mathrm{RhSi}$ : C, 50.44, $\mathrm{H}, 7.81, \mathrm{~N}, 4.52$. Found: C, 50.5, H, 7.86 $\mathrm{N}, 4.32 .{ }^{1} \mathrm{H}$ NMR $\left(300 \mathrm{MHz}, \mathrm{C}_{6} \mathrm{D}_{6}, 298 \mathrm{~K}\right): \delta 6.69\left(\mathrm{~d}, 1 \mathrm{H}, \mathrm{J}_{\mathrm{H}-\mathrm{H}}=2 \mathrm{~Hz}\right.$, $\left.\mathrm{CH}_{\text {imd }}\right), 6.35\left(\mathrm{~d}, 1 \mathrm{H}, J_{\mathrm{H}-\mathrm{H}}=2 \mathrm{~Hz}, \mathrm{CH}_{\text {imd }}\right), 5.36\left(\mathrm{~s}, 2 \mathrm{H}, \mathrm{CH}_{\mathrm{COD}}\right), 4.82$ (ddd, $1 \mathrm{H}, J_{\mathrm{H}-\mathrm{H}}=14 \mathrm{~Hz}, J_{\mathrm{H}-\mathrm{H}}=5 \mathrm{~Hz}, J_{\mathrm{H}-\mathrm{H}}=4 \mathrm{~Hz}, \mathrm{CH}_{2} \mathrm{O}$ ), 4.52 (ddd, $1 \mathrm{H}, J_{\mathrm{H}-\mathrm{H}}=$ $\left.13 \mathrm{~Hz}, J_{\mathrm{H}-\mathrm{H}}=9 \mathrm{~Hz}, J_{\mathrm{H}-\mathrm{H}}=6 \mathrm{~Hz}, \mathrm{CH}_{2} \mathrm{~N}^{(1)}\right), 4.25\left(\mathrm{~m}, 3 \mathrm{H}, \mathrm{CH}^{-} \mathrm{PrO}\right.$ and $1 \mathrm{H}$, $\mathrm{CH}_{2} \mathrm{~N}^{(1)}, 1 \mathrm{H} \mathrm{CH} \mathrm{H}_{2} \mathrm{O}$ ), 3.73 (ddd, $1 \mathrm{H}, \mathrm{J}_{\mathrm{H}-\mathrm{H}}=10 \mathrm{~Hz}, \mathrm{~J}_{\mathrm{H}-\mathrm{H}}=8 \mathrm{~Hz}, \mathrm{~J}_{\mathrm{H}-\mathrm{H}}=4 \mathrm{~Hz}$, $\left.\mathrm{CH}_{2} \mathrm{~N}^{(3)}\right), 3.52$ (ddd, $\left.1 \mathrm{H}, J_{\mathrm{H}-\mathrm{H}}=10 \mathrm{~Hz}, \mathrm{~J}_{\mathrm{H}-\mathrm{H}}=5 \mathrm{~Hz}, \mathrm{~J}_{\mathrm{H}-\mathrm{H}}=4 \mathrm{~Hz}, \mathrm{CH}_{2} \mathrm{~N}^{(3)}\right)$, $3.26(\mathrm{~m}, 2 \mathrm{H}, \mathrm{CH}$ COD $), 3.00\left(\mathrm{~s}, 3 \mathrm{H}, \mathrm{CH}_{3} \mathrm{O}\right), 2.41-2.13(\mathrm{~m}, 4 \mathrm{H} \mathrm{CH} 2 \mathrm{COD}$, $\left.1 \mathrm{H}-\mathrm{CH}_{2}-\right), 2.03\left(\mathrm{~m}, 1 \mathrm{H},-\mathrm{CH}_{2}-\right), 1.80\left(\mathrm{~m}, 4 \mathrm{H}, \mathrm{CH}_{2 \mathrm{COD}}\right), 1.21$ (vdd, $18 \mathrm{H}$ $\left.J_{\mathrm{H}-\mathrm{H}}=6 \mathrm{~Hz} J_{\mathrm{H}-\mathrm{H}}=3 \mathrm{~Hz}, \mathrm{CH}_{3}{ }^{-} \mathrm{PrO}\right), 0.74\left(\mathrm{~m}, 2 \mathrm{H}, \mathrm{CH}_{2} \mathrm{Si}\right) .{ }^{13} \mathrm{C}\left\{{ }^{1} \mathrm{H}\right\} \mathrm{NMR}$ $\left(75 \mathrm{MHz}, \mathrm{C}_{6} \mathrm{D}_{6}, 293 \mathrm{~K}\right): \delta 183.2\left(\mathrm{~d}, J_{\mathrm{Rh}-\mathrm{C}}=52 \mathrm{~Hz}, \mathrm{Rh} C_{\text {Carbene }}\right), 122.0$ $\left(\mathrm{CH}_{\text {imd }}\right), 120.0\left(\mathrm{CH}_{\text {imd }}\right), 98.1$ (d, $\left.J_{\text {Rh-C }}=7 \mathrm{~Hz}, 2 \mathrm{C}, \mathrm{CH}_{\mathrm{COD}}\right), 72.1$ $\left(\mathrm{CH}_{2} \mathrm{~N}^{(3)}\right), 67.7\left(\mathrm{~d}, J_{\mathrm{Rh}-\mathrm{C}}=14 \mathrm{~Hz}, \mathrm{CH}_{\mathrm{COD}}\right), 67.3\left(\mathrm{~d}, J_{\mathrm{Rh}-\mathrm{C}}=14 \mathrm{~Hz}\right.$ $\left.\mathrm{CH}_{\text {COD }}\right), 65.0(\mathrm{CH}-\mathrm{PrO}), 58.6\left(\mathrm{CH}_{3} \mathrm{O}\right), 53.5\left(\mathrm{CH}_{2} \mathrm{~N}^{(1)}\right), 51.0\left(\mathrm{CH}_{2} \mathrm{O}\right)$, $33.6\left(\mathrm{CH}_{2 \mathrm{COD}}\right), 33.3\left(\mathrm{CH}_{2 \mathrm{COD}}\right), 29.5\left(\mathrm{CH}_{2 \mathrm{COD}}\right), 29.2\left(\mathrm{CH}_{2 \mathrm{COD}}\right), 25.9$ $\left(\mathrm{CH}_{3}{ }^{-} \mathrm{PrO}\right), 25.4\left(-\mathrm{CH}_{2}{ }^{-}\right), 10.0\left(\mathrm{CH}_{2} \mathrm{Si}\right)$. MS $\left(\mathrm{ESI}^{+}\right): \mathrm{m} / \mathrm{z} 583.1\left(\mathrm{M}^{+}\right)$.

Immobilization of 3b on MCM-41: To a suspension of MCM-41 $(0.50$ $\mathrm{g})$ in wet toluene $(10.0 \mathrm{~mL})$ a solution of $3 \mathbf{b}(50 \mathrm{mg})$ in toluene $(5.0$ $\mathrm{mL}$ ) was added. The reaction slurry was refluxed and stirred for $24 \mathrm{~h}$. The resulting mixture was cooled down to r.t. The solid was separated by decantation and washed with toluene $(10 \mathrm{~mL})$, dichloromethane $(2 \times 10 \mathrm{~mL})$ and diethylether $(10 \mathrm{~mL})$ and dried in vacuo at $60{ }^{\circ} \mathrm{C}$ to afford an off-white solid. Yield $0.484 \mathrm{~g}(96.8 \%)$. Found: $\mathrm{C}, 6.23, \mathrm{H}$, 1.14, N, 0.43, Rh, $1.63(16.320 \mathrm{mg} / \mathrm{g})$. FT-IR: $1636 \mathrm{~cm}^{-1}$ (br.), v(C=N) and $v(C=C), 1241 \mathrm{~cm}^{-1}, 1043 \mathrm{~cm}^{-1}, 800 \mathrm{~cm}^{-1} \mathrm{v}(\mathrm{Si}-\mathrm{O}-\mathrm{Si}) .{ }^{13} \mathrm{C}-\mathrm{RMN} \mathrm{CP}-$ MAS: $\delta 122.5\left(\mathrm{CH}_{\text {imd }}\right), 86.4\left(\mathrm{CH}_{\mathrm{COD}}\right), 73.9\left(\mathrm{CH}_{2} \mathrm{~N}^{(3)}\right), 69.8\left(\mathrm{CH}_{\mathrm{COD}}\right)$, $66.9\left(\mathrm{CH}_{\mathrm{COD}}\right), 57.1\left(\mathrm{CH}_{3} \mathrm{O}\right), 50.7\left(\mathrm{CH}_{2} \mathrm{~N}^{(1)}\right), 49.2\left(\mathrm{CH}_{2} \mathrm{O}\right), 36.0-18.0$ $\left(\mathrm{CH}_{2 \mathrm{COD}}\right.$ and $\left.-\mathrm{CH}_{2}^{-}\right), 8.4\left(\mathrm{CH}_{2} \mathrm{Si}\right)$.
Synthesis of $\mathrm{PhCHMeOSi}\left(\mathrm{OSiMe}_{3}\right)_{2} \mathrm{Me}$ (4): A mixture of 1,1,1,3,5,5,5heptamethylsiloxane $(1.0 \mathrm{~mL})$, acetophenone $(1.0 \mathrm{mmol}, 0.12 \mathrm{~mL})$ and the corresponding catalyst $(0.01 \mathrm{mmol})$ was stirred under argon at $80{ }^{\circ} \mathrm{C}$ for $16 \mathrm{~h}$. After cooling to room temperature methanol $(5 \mathrm{~mL})$ and water $(2 \mathrm{~mL})$ were added. The mixture was extracted with diethyl ether $(3 \times 5 \mathrm{~mL})$, and the resulting diethyl ether solution was dried over anhydrous $\mathrm{MgSO}_{4}$. The solution was filtered through silica and the solvent removed in vacuo to afford yellowish oil. ${ }^{1} \mathrm{H}$ NMR $(300$ $\left.\mathrm{MHz}, \mathrm{CDCl}_{3}, 298 \mathrm{~K}\right)$ : $\delta$ 7.39-7.30 (m, 4H, CH), 7.25-7.20 (m, 1H, CH), $5.04\left(\mathrm{q}, 1 \mathrm{H}, \mathrm{J}_{\mathrm{H}-\mathrm{H}}=7 \mathrm{~Hz}, \mathrm{CHO}\right), 1.48\left(\mathrm{~d}, 3 \mathrm{H}, \mathrm{J}_{\mathrm{H}-\mathrm{H}}=7 \mathrm{~Hz}, \mathrm{CH}_{3} \mathrm{CHO}\right.$ ), $\left.0.12\left(\mathrm{~s}, 6 \mathrm{H}, \mathrm{SiCH}_{3}\right), 0.07\left(\mathrm{~s}, 6 \mathrm{H}, \mathrm{SiCH}_{3}\right), 0.04\left(\mathrm{~s}, 3 \mathrm{H}, \mathrm{SiCH}_{3}\right) .{ }^{13} \mathrm{C}^{1} \mathrm{H}\right\}$ NMR $\left(75 \mathrm{MHz}, \mathrm{CDCl}_{3}, 293 \mathrm{~K}\right)$ : $\delta 146.2\left(C_{\text {ipso }}\right), 128.0(2 \mathrm{C}, \mathrm{CH}), 126.6$ $(\mathrm{CH}), 125.3(2 \mathrm{C}, \mathrm{CH}), 70.0(\mathrm{CHO}), 26.6\left(\mathrm{CH}_{3} \mathrm{CHO}\right), 1.7\left(2 \mathrm{C}, \mathrm{SiCH}_{3}\right)$, $1.6\left(2 \mathrm{C}, \mathrm{SiCH}_{3}\right),-3.2\left(\mathrm{SiCH}_{3}\right) . \mathrm{MS}\left(\mathrm{ESI}^{+}\right): \mathrm{m} / \mathrm{z} 373.2\left(\mathrm{M}^{+}\right)$.

Hydrosilylation of acetophenone: homogeneous catalysis: A mixture of 1,1,1,3,5,5,5-heptamethylsiloxane $(2 \mathrm{~mL})$, the corresponding catalyst $(13.3 \mathrm{mg}(\mathbf{3 a}), 12.4 \mathrm{mg}(\mathbf{3 b}), 0.02 \mathrm{mmol})$, acetophenone $(0.234 \mathrm{~mL}, 2 \mathrm{mmol})$ and mesitylene $(0.234 \mathrm{~mL}, 2 \mathrm{mmol}$, internal standard) was stirred at $80^{\circ} \mathrm{C}$. Samples were taken at regular time intervals and analyzed by gas chromatography.

Hydrosilylation of acetophenone: heterogeneous catalysis: A mixture of 1,1,1,3,5,5,5-heptamethylsiloxane (2 mL), 3b-MCM-41 (14.8 mg, $0.002 \mathrm{mmol})$, acetophenone $(0.023 \mathrm{~mL}, 0.2 \mathrm{mmol})$ and mesitylene $(0.0234 \mathrm{~mL}, 0.2 \mathrm{mmol}$, internal standard) was stirred under argon at $80^{\circ} \mathrm{C}$. Samples were taken at regular time intervals and analyzed by gas chromatography.

NMR studies of the hydrosilylation of acetophenone: An NMR tube was charged under argon with 1,1,1,3,5,5,5-heptamethylsiloxane $(0.271 \mathrm{~mL}, 1.0 \mathrm{mmol})$, the corresponding catalyst $(66.4 \mathrm{mg} \mathrm{(3a)}), 62.0$ $\mathrm{mg}(3 \mathrm{~b}), 0.1 \mathrm{mmol})$ acetophenone $(0.120 \mathrm{~mL}, 1.0 \mathrm{mmol})$ and $\mathrm{C}_{6} \mathrm{D}_{6}$ $(0.5 \mathrm{~mL})$. The reaction was monitored by ${ }^{1} \mathrm{H} \mathrm{NMR}$ from $25^{\circ} \mathrm{C}$ to $90^{\circ} \mathrm{C}$.

Recycling of the heterogeneous catalyst: The reaction mixture was centrifuged and 3b-MCM41 separated from the product by decantation, dried in vacuo and reused without further purifications.

Co-polimerization by homogeneous catalytic hydrosilyation: 1,4Dioxane (2 $\mathrm{mL})$ was added to a mixture of $1,1,3,3,5,5-$ hexamethylsiloxane $(0.254 \mathrm{~mL}, 1 \mathrm{mmol}$,$) terephthalaldehyde (134.13$ $\mathrm{mg}, 1 \mathrm{mmol})$ and $3 \mathrm{~b}(12.4 \mathrm{mg}, 0.02 \mathrm{mmol})$. The reaction mixture was stirred at $110^{\circ} \mathrm{C}$ for 4 days. The resulting mixture was filtered through celite and the solvent removed in vacuo to afford orange oil. Yield 330 $\mathrm{mg}(96 \%)$

Co-polimerization by heterogeneous catalytic hydrosilylation: 1,4Dioxane $(2 \mathrm{~mL})$ was added to a mixture of $1,1,3,3,5,5$ hexamethylsiloxane $(0.025 \mathrm{~mL}, 0.1 \mathrm{mmol}$,), terephthalaldehyde $(13.4$ $\mathrm{mg}, 0.1 \mathrm{mmol}$,) and $\mathbf{3 b}-\mathbf{M C M}-41(14.8 \mathrm{mg}, 0.002 \mathrm{mmol})$. The reaction mixture was stirred at $110^{\circ} \mathrm{C}$ for 4 days. The resulting mixture was filtered through celite and the solvent removed in vacuo to afford orange oil. Yield $30.8 \mathrm{mg}(90 \%)$.

Data for polymer 5: ${ }^{1} \mathrm{H}$ NMR plus COSY $\left(400 \mathrm{MHz}, \mathrm{CD}_{2} \mathrm{Cl}_{2}, 298 \mathrm{~K}\right)$ : $\delta$ $7.29(\mathrm{~s}, 4 \mathrm{H}, \mathrm{CH}), 4.75\left(\mathrm{~s}, 4 \mathrm{H}, \mathrm{CH}_{2}\right), 0.14\left(\mathrm{~s}, 12 \mathrm{H}, \mathrm{SiCH}_{3}\right), 0.11(\mathrm{~s}, 6 \mathrm{H}$, $\left.\mathrm{SiCH}_{3}\right) .{ }^{13} \mathrm{C}\left\{{ }^{1} \mathrm{H}\right\}$ NMR plus APT $\left(101 \mathrm{MHz}, \mathrm{CD}_{2} \mathrm{Cl}_{2}, 298 \mathrm{~K}\right): \delta 140.31$ $\left(2 \mathrm{C}, \mathrm{C}_{\text {ipso }}\right), 126.99(4 \mathrm{C}, \mathrm{CH}), 64.44\left(2 \mathrm{C}, \mathrm{CH}_{2}\right), 1.18\left(2 \mathrm{C}, \mathrm{CH}_{3}\right),-0.72$ $\left(4 \mathrm{C}, \mathrm{CH}_{3}\right) .{ }^{29} \mathrm{Si} N M R\left(60 \mathrm{MHz}, \mathrm{CD}_{2} \mathrm{Cl}_{2}, 298 \mathrm{~K}\right): \delta-11.45(2 \mathrm{Si}$, $\left.\mathrm{Si}\left(\mathrm{CH}_{3}\right)_{2}\right),-20.82\left(1 \mathrm{Si}, \mathrm{Si}\left(\mathrm{CH}_{3}\right)_{2}\right)$.

\section{Acknowledgements}

Financial support from the Spanish "Ministerio de Economia $y$ Competividad" projects CTQ2010-15221, CSD2009-00050 CONSOLIDER INGENIO-2010, CTQ2011-27593, "Ramon y Cajal" 
program (P. J. S. M.), “Juan de la Cierva” program (M. I.) and "Diputación General de Aragón" group E07 is acknowledged.

Keywords: Poly(silyl ether)s • Hydrosilylation • Rhodium-NHC - Homogeneous Catalysis • Heterogeneous Catalysis

[1] (a) A. K. Roy, Adv. Organomet. Chem. 2008, 55, 1-59. (b) B. Marciniec, K. H. Maciejewski, C. Pietraszuk, P. Pawluć, Hydrosililation: A Comprehensive Review on Recent Advances (Ed: B. Marciniec), Springer, London, 2008.

[2] (a) I. Chorkendorff, J. W. Niemantsverdriet, In Concepts of Modern Catalysis and Kinetics; Wiley-VCH; Weinheim, 2003. (b) G. Rothenberg In Catalysis: Concepts and Green Applications; Wiley-VCH: Weinheim, 2008. (c) B. Marciniec, K. Szubert, M. J. Potrzebowski, I. Kownacki, H Maciejewski, ChemCatChem 2009, 1, 304-310.

[3] (a) C. E. Song, S. Lee, Chem. Rev. 2002, 102, 3495-3524. (b) D. E. De Vos, M. Dams, B. F. Sels, P. A. Jacobs, Chem. Rev. 2002, 102, 36153640. (c) P. McMorn, G. J. Hutchings, Chem. Soc. Rev. 2004, 33, 108122. (d) M. Tada, Y. Iwasawa, Coord. Chem. Rev. 2007, 251, 2702-2716.

[4] (a) W. A. Herrmann, M. Elison, J. Fischer, C. Köcher, G. R. J. Artus, Angew. Chem. Int. Ed. Engl. 1995, 34, 2371-2374. (b) W. Kirmse, Angew. Chem. Int. Ed. 2010, 49, 8798-8801.

[5] S. Díez-González, N. Marion, S. P. Nolan, Chem. Rev. 2009, 109, 3612 3676 .

[6] (a) J. Schwarz, V. P. W. Böhm, M. G. Gardiner, M. Grosche, W. A Herrmann, W. Hieringer, G. Raudaschl-Sieber, Chem. Eur. J. 2000, 6, 1773-1780. (b) L. Yang, M. Mayr, K. Wurst, M. R. Buchmeiser, Chem. Eur. J. 2004, 10, 5761-5770.(c) Ö. Aksın, H. Türkmen, L. Artok, B. Çetinkaya, C. Ni, O. Büyükgüngör, E. Özkal, J. Organomet. Chem. 2006, 691, 3027-3036. (d) W. J. Sommer, M. Weck, Coord. Chem. Rev. 2007, 251, 860-873. (e) C. del Pozo, N. Debono, A. Corma, M. Iglesias, F. Sánchez, ChemSusChem 2009, 2, 650-657. (f) A. Arnanz, C. GonzálezArellano, A. Juan, G. Villaverde, A. Corma, M. Iglesias, F. Sánchez, Chem. Commun. 2010, 46, 3001-3003. (g) M. Boronat, A. Corma, C. González-Arellano, M. Iglesias, F. Sánchez, Organometallics 2010, 29 134-141.

[7] K. Riener, M. P. Högerl, P. Gigler, F. E. Kühn, ACS Catal. 2012, 2, 613-621.

[8] (a) I. Ojima, M. Nihonyanagi, T. Kogure, M. Kumagai, S. Horiuchi, K Nakatsugawa, Y. Nagai, J. Organomet. Chem. 1975, 94, 449-461. (b) I. Ojima, T. Kogure, M. Kumagai, S. Horiuchi, T. Sato, J. Organomet. Chem. 1976, 122, 83-97. (c) G. Z. Zheng, T. H. Chan, Organometallics 1995, 14, 70-79. (d) N. Schneider, M. Finger, C. Haferkemper, S. Bellemin-Laponnaz, P. Hofmann, L. H. Gade, Angew. Chem., Int. Ed. 2009, 48, 1609-1613. (e) N. Schneider, M. Finger, C. Haferkemper, S Bellemin-Laponnaz, P. Hofmann, L. H. Gade, Chem. Eur. J. 2009, 15 11515-11529. (f) P. Gigler, B. Bechlars, W. A. Herrmann, F. E. Kühn, J Am. Chem. Soc. 2011, 133, 1589-1596.

[9] For a review see: S. Putzien, O. Nuyken, F. E. Kühn, Prog. Polym. Sci. 2010, 35, 687-713.

[10] (a) J. M. Mabry, J. K. Paulasaari, W. P. Weber, Polymer 2000, 41, 4423 4428. (b) J. M. Mabry, M. K. Runyon, W. P. Weber, Macromolecules 2002, 35, 2207-2211.

[11] M. G. Voronkov, V. P. Mileshkevich, Y. A. Yuzhelevskii, In The Siloxane Bond; Consultants Bureau: New York, 1978. Si-O-Si, pp 146-149; Si-O-C pp 323-340

[12] (a) Y. Nagasaki, F. Matsukura, M. Kato, H. Aoki, T. Tokuda, Macromolecules 1996, 29, 5859-5863. (b) K. E. Uhrich, S. M. Cannizzaro, R. S. Langer, K. M. Shakesheff, Chem. Rev. 1999, 99 3181-3198. (c) A. M. Issam, M. Haris, J. Inorg. Organomet. Polym. 2009, 19, 454-458.

[13] D.-J. Liaw, Polymer 1997, 38, 5217-5219 and references therein

[14] J. K. Paulasaari, W. P. Weber, Macromolecules 1998, 31, 7105-7107.

[15] (a) M. V. Jiménez, J. J. Pérez-Torrente, M. I. Bartolomé, V. Gierz, J. Lahoz, L. A. Oro, Organometallics 2008, 27, 224-234. (b) M. V. Jiménez, J. Fernández-Tornos, J. J. Pérez-Torrente, F. J. Modrego, S. Winterle, C. Cunchillos, F. J. Lahoz, L. A. Oro, Organometallics 2011, 30, 5493-5508.

[16] (a) M. V. Jiménez, J. J. Pérez-Torrente, M. I. Bartolomé, E. Vispe, F. J. Lahoz, L. A. Oro, Macromolecules 2009, 42, 8146-8156. (b) V. César, S. Bellemin-Laponnaz, L. H. Gade, Chem. Soc. Rev. 2004, 33, 619-636. (c)
M. Albrecht, G. van Koten, Angew. Chem., Int. Ed. 2001, 40, 3750-3781. (d) I. P. Beletskaya, A. V. Cheprakov, Chem. Rev. 2000, 100, 3009-3066

[17] (a) A. Di Giuseppe, R. Castarlenas, J. J. Pérez-Torrente, F. J. Lahoz, V. Polo, L. A. Oro, Angew. Chem. Int. Ed. 2011, 50, 3938-3942. (b) L. Palacios, X. Miao, A. Di Giuseppe, S. Pascal, C. Cunchillos, R. Castarlenas, J. J. Pérez-Torrente, F. J. Lahoz, P. H. Dixneuf, L. A. Oro, Organometallics 2011, 30, 5208-5213. (c) I. Mena, M. A. Casado, P. García-Orduña, V. Polo, F. J. Lahoz, A. Fazal, L. A. Oro, Angew. Chem. Int. Ed. 2011, 50, 11735-11738.

[18] W. A. Herrmann, Angew. Chem. Int. Ed. 2002, 41, 1290-1309.

[19] (a) K. H. Park, S. Kim, Y. K. Chung, Bull. Korean Chem. Soc. 2008, 29, 2057-2060. (b) S. Dastgir, K. S. Coleman, M. L. H. Green, Dalton Trans. 2011, 40, 661-672.

[20] C. S. J. Cazin, M. Veith, P. Braunstein, R. B. Bedford, Synthesis, 2005, 622-626.

[21] (a) C. del Pozo, A. Corma, M. Iglesias, F. Sánchez, Organometallics 2010, 29, 4491-4498. (b) G. Villaverde, A. Corma, M. Iglesias, F. Sánchez, ChemCatChem 2011, 3, 1320-1328.

[22] (a) Z. Fei, W. H. Ang, D. Zhao, R. Scopelliti, E. E. Zvereva, S. A. Katsyuba, P. J. Dyson, J. Phys. Chem. B. 2007, 111, 10095-10108. (b) X Yang, Z. Fei, T. J. Geldbach, A. D. Phillips, C. G. Hartinger, Y. Li, P. J. Dyson, Organometallics 2008, 27, 3971-3977.

[23] K. Fagnou, M. Lautens, Angew. Chem. Int. Ed. 2002, 41, 26-47.

[24] I. Ojima, M. Nihonyanagi, Y. Nagai, J. Chem. Soc. Chem. Commun. 1972, 938a-938a.

[25] R. Uson, L. A. Oro, J. A. Cabeza, Inorg. Synth. 1985, 23, 126-130.

[26] APEX2 Bruker AXS Inc., Madison, Wisconsin, USA, 2011.

[27] (a) G. M. Sheldrick, SHELXS-97 and SHELXL-97; University of Göttingen, Germany, 1997. (b) L. J. Farrugia, WinGX; University of Glasgow, Great Britain, 1998 
